\title{
Distribution and Status of Uncommon Mammals in the Southern Appalachian Mountains
}

\author{
Joshua W. Campbell ${ }^{~}$, Michael T. Mengak ${ }^{2, *}$, Steven B. Castleberry ${ }^{2}$, \\ and Jason D. Mejia ${ }^{3}$
}

\begin{abstract}
Knowledge of species distribution is fundamental to conservation and management efforts. Unfortunately, distribution of many mammal species in the southeastern United States, including some considered endangered, threatened, or of special concern, has been and remains poorly documented. We queried museums, reviewed the published literature, and searched state Natural Heritage Inventory databases to obtain distributional information for 13 mammal species considered rare (Global Rank G1-G3 or State Rank S1-S3) or of other conservation concern in the Southern Appalachian region. We constructed distribution maps for selected mammal species within the region based on 7 state Natural Heritage Inventory databases and 1539 county records from 26 museums and 57 published sources. Napaeozapus insignis (Woodland Jumping Mouse), Mustela nivalis (Least Weasel), and Tamiasciurus hudsonicus (Red Squirrel) exhibited large (>150 km) geographic differences from currently accepted range maps. Sorex dispar (Rock Shrew), Synaptomys cooperi (Southern Bog Lemming), Neotoma magister (Allegheny Woodrat), and Zapus hudsonius (Meadow Jumping Mouse), exhibited small $(<75 \mathrm{~km})$ geographic differences. The remaining 6 species showed little to no range differences from commonly accepted range maps. Because seven of 13 mammals showed substantial differences from known range maps, our updated maps may aide managers and others in focusing surveying and conservation efforts.
\end{abstract}

\section{Introduction}

Numerous federal and state agencies have mandates to assess and monitor the status of species with high conservation interest and to make management recommendations to ensure the continued existence of these species (Clark et al. 1994). For example, state wildlife action plans, recently formulated by state wildlife departments, require current information on species status and distribution to accurately plan future conservation needs. Unfortunately, basic natural history information required to make recommendations, including species distributions, does not exist or is incomplete for many species, especially in the southeastern United States. Of particular concern is the lack of distributional information for many species that are state or federally designated as endangered or threatened, making development of recommendations to recover species difficult (Trani et al. 2007). Accurate information on species distribution is essential to agencies for

\footnotetext{
${ }^{1}$ Department of Sciences and Mathematics, Shorter College, Rome, GA 30165. ${ }^{2}$ Warnell School of Forestry and Natural Resources, University of Georgia, Athens, GA 30602. ${ }^{3}$ California State University, Northridge, Department of Geography, Northridge, CA 91330-8249. "Corresponding author - mmengak@warnell.uga.edu.
} 
reducing exposure to regulatory liability when conducting management activities within the range of listed species.

Dobson et al. (1997) reviewed the distributions of endangered species in the United States and identified the Southern Appalachian Mountains as a "hot spot of threatened biodiversity." Over 77\% (78 of 101 species) of terrestrial mammals in the Southeast are considered "sensitive", defined as being state or federally listed as endangered, threatened, or of special concern, or as being monitored by state Natural Heritage Inventory programs (Laerm et al. 2000). Laerm et al. (2000) concluded that with the exception of federally endangered or threatened species, information on the taxonomy, distribution, and life history necessary to ascertain status is inadequate for many southeastern mammalian taxa. Many mammals considered rare or of concern by state and federal wildlife agencies may reflect a lack of knowledge regarding species distribution. Thus, revised assessments of distribution and population status of endangered and/or rare (sensitive) species in the Southern Appalachians are needed.

Habitat loss and habitat fragmentation are considered the primary threats to many mammals in the South (Trani et al. 2007). Several recent papers have reviewed the conservation status of southeastern mammals, including mammals in general (Laerm et al. 2000), bats (Menzel et al. 2000, 2003) and those in the Pinus palustris P. Mill. (Longleaf Pine) ecosystem (Smith et al. 2006), but none have targeted sensitive terrestrial mammalian taxa of the Southern Appalachian Mountains. A necessary first step in acquiring the information needed to develop effective conservation strategies for sensitive mammals of the Southern Appalachians is to determine current species distributions. Thus, our objective was to compile updated, county-specific distributional information from Natural Heritage databases, published literature, and museum collections on small terrestrial mammals considered rare in the Southern Appalachians.

\section{Methods}

The Southern Appalachian region has been defined differently by various authors (Brooks 1971, Redington 1978). We considered the Southern Appalachian region as the portions of the Blue Ridge, Ridge and Valley, and Allegheny and Cumberland plateaus in Alabama, Georgia, Kentucky, North Carolina, South Carolina, Tennessee, and Virginia (Fenneman 1938). The region is bordered to the east and south by the Piedmont and to the west by the Interior Low Plateaus (Fig. 1).

We selected 13 mammal species found in the Southern Appalachian region based on their apparent rarity in the region and/or a lack of information pertaining to their current distributions (Laerm et al. 2000; Table 1). The species included Sorex dispar Batchelder (Rock Shrew or Long-tailed Shrew), Sorex palustris Richardson (Water Shrew), Lepus americanus Erxleben (Snowshoe Hare), Sylvilagus obscurus Chapman, Cramer, Deppenaar, and Robinson (Appalachian Cottontail), Microtus chrotorrhinus Miller (Rock Vole), Neotoma magister Baird (Allegheny Woodrat), Synaptomys cooperi Baird (Southern 
Bog Lemming), Glaucomys sabrinus Shaw (Northern Flying Squirrel), Tamiasciurus hudsonicus Erxleben (Red Squirrel), Napaeozapus insignis Miller (Woodland Jumping Mouse), Zapus hudsonius Zimmermann (Meadow Jumping Mouse), Spilogale putorius L. (Eastern Spotted Skunk), and Mustela nivalis

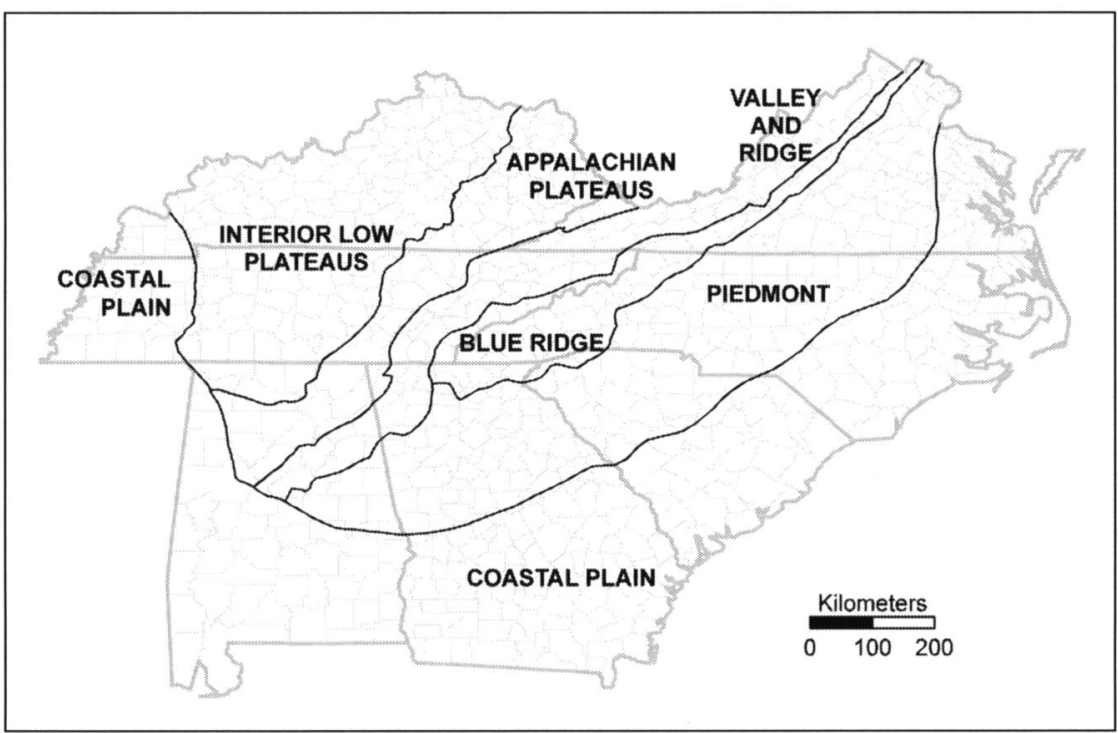

Figure 1. States and counties included within the geographic provinces we considered to encompass the Southern Appalachian Mountains and used for our distribution maps of selected mammals.

Table 1. State and federal protection status of 13 small mammals based on The Nature Conservancy/Natural Heritage Program listing (from Trani et al. 2007).

\begin{tabular}{|c|c|c|c|c|c|c|c|c|}
\hline \multirow[b]{2}{*}{ Species } & \multicolumn{7}{|c|}{ State status ${ }^{A}$} & \multirow{2}{*}{$\begin{array}{c}\text { Federal } \\
\text { status }^{B}\end{array}$} \\
\hline & $\mathrm{AL}$ & GA & KY & $\mathrm{NC}$ & $\mathrm{SC}$ & $\mathrm{TN}$ & VA & \\
\hline Sorex dispar & & S1 & S1 & S3 & S2 & S2 & S3 & $\mathrm{N} 4$ \\
\hline Sorex palustris & & S1 & & S2 & SNR & S2 & S1 & N5 \\
\hline Lepus americanus & & & & $\mathrm{SX}$ & & & S1 & N5 \\
\hline Sylvilagus obscurus & $\mathrm{S} 1$ & $\mathrm{~S} 1 / \mathrm{S} 2$ & SU & S3 & S3 & S3 & S4? & $\mathrm{N} 4$ \\
\hline Microtus chrotorrhinus & & & & S3 & SNR & SNR & $\mathrm{S} 1$ & N4 \\
\hline Neotoma magister & S3 & $\mathrm{SC}$ & S4 & S2 & & S3 & S3 & $\mathrm{N} 3 / \mathrm{N} 4$ \\
\hline Synaptomys cooperi & & S1 & S4 & S3 & SNR & S4 & S5 & N5 \\
\hline Glaucomys sabrinus & & & & S2 & & SNR & S1 & N5 \\
\hline Tamiasciurus hudsonicus & & S3 & & S5 & S3? & $\mathrm{S} 4 / \mathrm{S} 5$ & S5 & N5 \\
\hline Napaeozapus insignis & & S3 & S4 & S4? & S4 & S4 & S5 & N5 \\
\hline Zapus hudsonius & S3 & S3 & S4 & S3 & SNR & S4 & S5 & N5 \\
\hline Spilogale putorius & $\mathrm{S} 2 / \mathrm{S} 3$ & S4 & $\mathrm{S} 2 / \mathrm{S} 3$ & S3 & S4 & S3 & $\mathrm{S} 3 / \mathrm{S} 4$ & N5 \\
\hline Mustela nivalis & & $\mathrm{S} 1$ & $\mathrm{~S} 2 / \mathrm{S} 3$ & S2 & SNR & S2 & S3 & N5 \\
\hline
\end{tabular}

${ }^{\mathrm{A}} \mathrm{S} 1$ = critically imperiled in state, $\mathrm{S} 2=$ imperiled in state, $\mathrm{S} 3=$ vulnerable in state, $\mathrm{S} 4=$ uncommon but not rare, $\mathrm{S} 5=$ common, widespread, and abundant in state, SNR and $\mathrm{S}$ ? = conservation status not yet assessed, $\mathrm{SU}=$ currently unranked due to lack of information, $\mathrm{SX}$ $=$ believed to be extirpated from the state.

${ }^{\mathrm{B}} \mathrm{N} 3=$ vulnerable in nation, $\mathrm{N} 4=$ uncommon but not rare in nation, $\mathrm{N} 5=$ common, widespread, and abundant in nation. 
L. (Least Weasel). Although some of the species have distributions that extend outside of the Southern Appalachian region, our primary criterion for inclusion was a lack of up-to-date published distributional information within the Southern Appalachian region.

We requested collection records for our focal species from 50 museums across the United States. We compiled museum records and determined presence or absence for each species within each county in the region. We also reviewed the published literature for additional distributional data (e.g., confirmed captures, positive sightings, photographs) not found in museum records. In addition, we searched the on-line database at each state's Natural Heritage Inventory webpage. We accepted on-line data if the state classified the record as "known" or "historic" and rejected records classified as "suspected", "probable", or other similar term. We combined county locations from databases, published literature, and museum records to produce maps of species distributions using ArcView 9.1 (ESRI 2005). The first iteration of our distribution maps was sent to selected mammalogists in the region for review with the additional request that they add information on distributions from their own field notes and other experience. Although we recognize that the reliability of our data sources may differ, we proceeded under the assumption of equal reliability. We recognize that maps are static depictions whereas actual species distribution is dynamic; therefore our maps represent the most accurate information at that moment in time when they were compiled. We established a cutoff date of December 2005 for data retrieval and map construction. For the purpose of the distributions, only species data were used because subspecies data did not exist for most museum records. Nomenclature follows Baker et al. (2003).

\section{Results and Discussion}

Of the 50 museums we contacted, 26 supplied information for our focal species, eight responded by saying they lacked specimens of interest, and 16 did not respond. We subsequently contacted 14 of the 16 museums that did not initially respond. Seven reported having no data for our species or area, and seven did not respond to further repeated contact attempts. We obtained 1539 museum records from 26 museums (Table 2). We obtained additional county records from 57 published sources and personal comunications (Table 3). We summarized the species' general distribution and habitat associations, as well as the distributional information obtained during our study in the following species' accounts.

\section{Sorex dispar Batchelder (Long-tailed or Rock Shrew)}

The Long-tailed Shrew is restricted to the Appalachian Mountains, ranging from southeastern North Carolina to Maine (Hall 1981). It is a habitat specialist found in high-elevation, rocky areas and cool, moist forests in the region (Ford et al. 2006, Pagels 1987). The species is considered rare in many areas of the Southern Appalachians (Laerm et al. 2000).

Our data did not indicate any large extensions of the accepted range of the species (Fig. 2). We found one record (UGAMNH) for Rabun County, $\mathrm{GA}$, which indicates a minor southward extension of its known range. Other 
Table 2. List of museums from which distributional data were obtained for 13 mammal species from the Southern Appalachians. Museum code follows Hafner et al. (1997).

Museum code Museum and location

\begin{tabular}{ll}
\hline ALMNH & Alabama Museum of Natural History, Tuscaloosa, AL \\
AMNH & American Museum of Natural History, New York, NY \\
ANSP & Philadelphia Academy of Natural Sciences, Philadelphia, PA \\
CAS & California Academy of Science, San Francisco, CA \\
CM & Carnegie Museum of Natural History, Pittsburgh, PA \\
CUVC & Cornell University, Ithaca, NY \\
CUSC & Clemson University Vertebrate Collection, Clemson, SC \\
FMNH & Field Museum of Natural History, Chicago, IL \\
LACM & Natural History Museum of Los Angeles County, CA \\
MSB & University of New Mexico, Museum of Southwestern Biology, Albuquerque, NM \\
MSU & Michigan State University, East Lansing, MI \\
MSUMC & Murray State University, Murray, KY \\
MVZ & Museum of Vertebrate Zoology, University of California-Berkeley, Berkeley, CA \\
NCSM & North Carolina State Museum of Natural Sciences, Raleigh, NC \\
USNM & National Museum of Natural History, Washington, D. C. \\
OMNH & Sam Noble Oklahoma Museum of Natural History, Norman, OK \\
UAM & University of Alaska-Fairbanks, Fairbanks, AK \\
UF & Florida Museum of Natural History, Gainesville, FL \\
UGAMNH & University of Georgia, Museum of Natural History, Athens, GA \\
UIMNH & University of Illinois Museum of Natural History, Urbana-Champaign, IL \\
UKNMH & University of Kansas, Manhattan, KS \\
UMMZ & University of Michigan, Ann Arbor, MI \\
UTC & University of Tennessee-Chattanooga, Natural History Museum \\
UWBM & University of Washington, Seattle, WA \\
VMNH & Virginia Museum of Natural History, Martinsville, VA \\
VTMNH & Virginia Tech Museum of Natural History, Blacksburg, VA \\
\hline
\end{tabular}

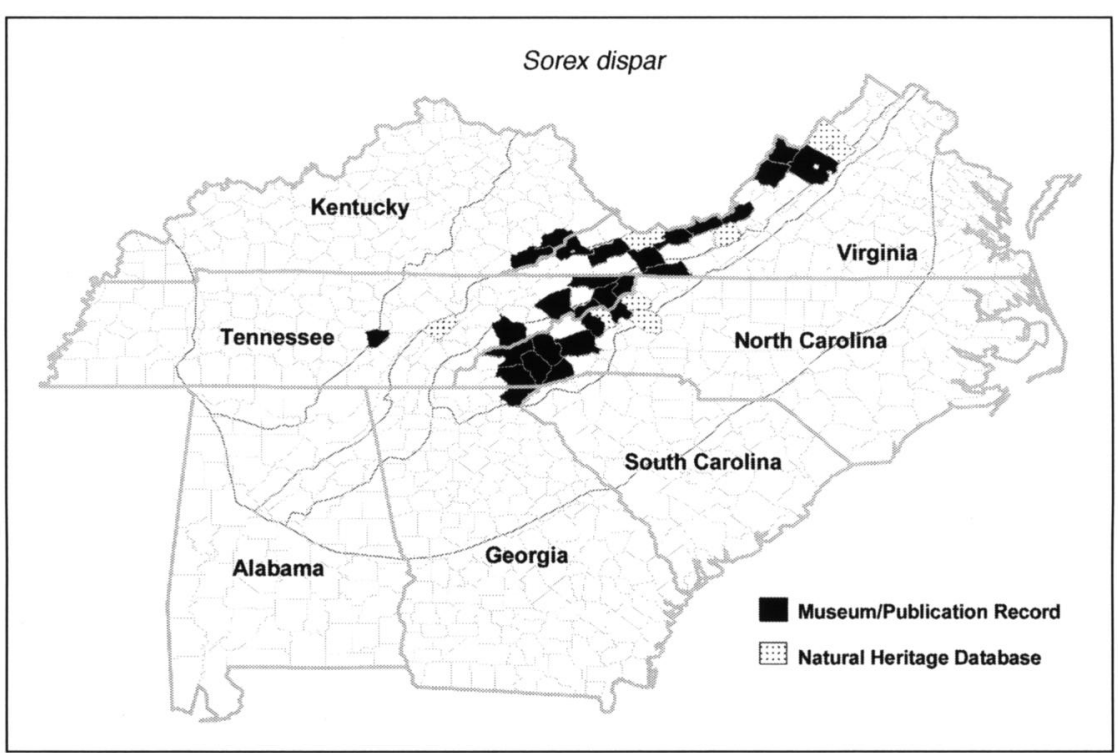

Figure 2. Counties with confirmed museum or publication records for Sorex dispar (Long-tailed Shrew) within the Southern Appalachian Mountains. 


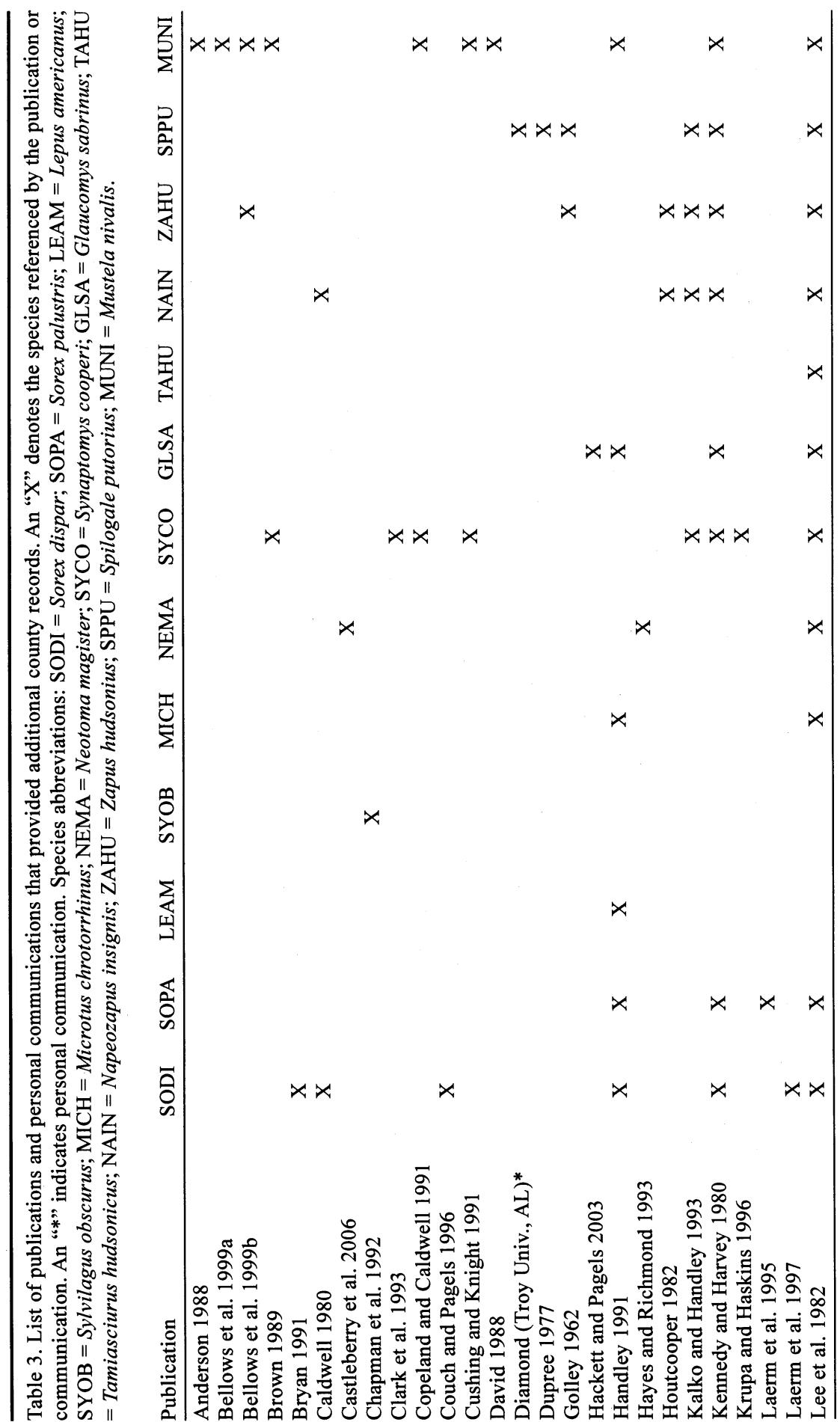




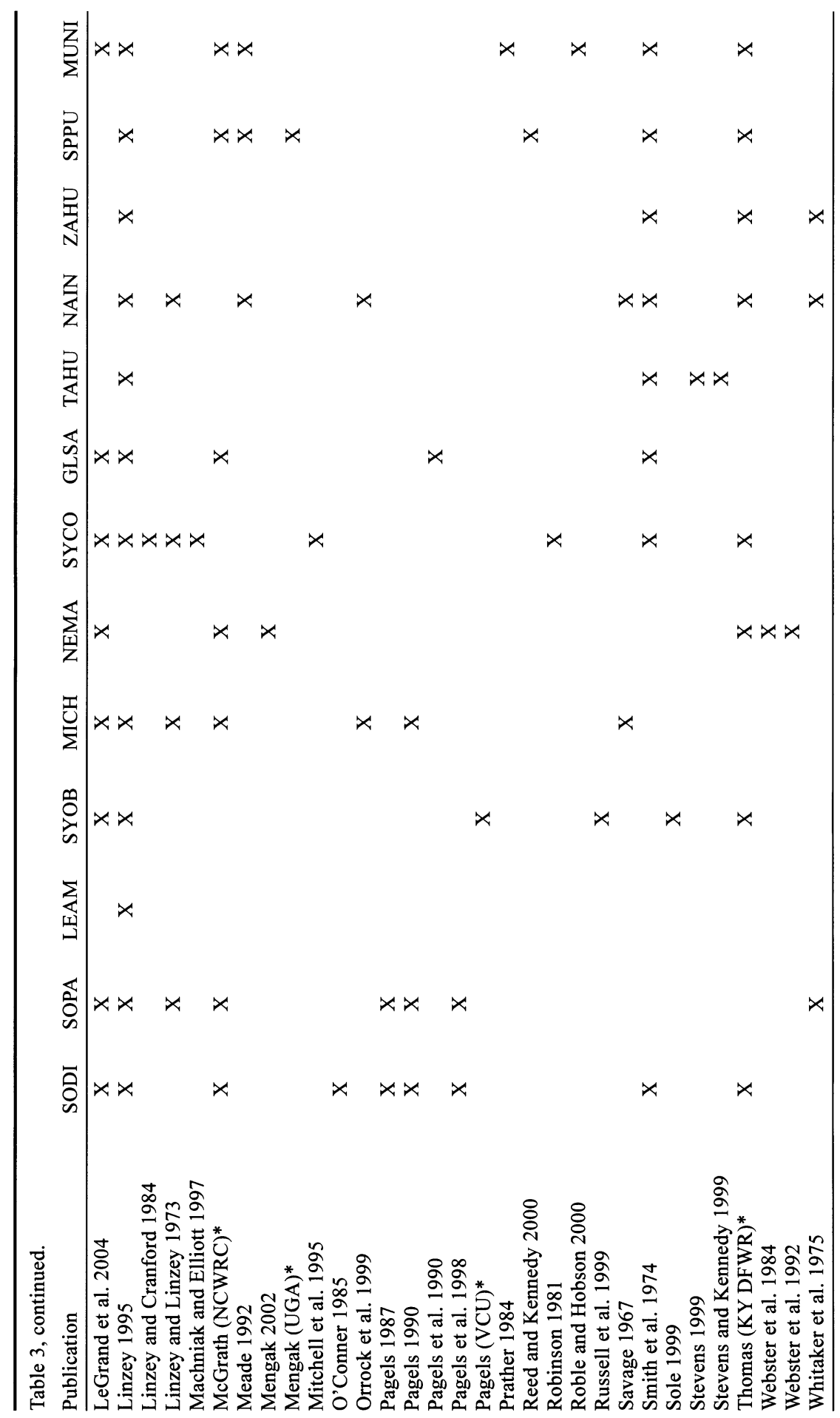


records from eastern Kentucky show the distribution farther west than previous range descriptions. Kennedy and Harvey (1980) mention specimens from Van Buren County, TN, which expands its range westward into Tennessee by approximately $200 \mathrm{~km}$. Although the species has not been documented from the state, Brown (1997) suggested that northern Alabama has potential habitat. Therefore, further searches could support a further westward and southern expansion into the Southern Appalachians.

\section{Sorex palustris Richardson (American Water Shrew)}

The American Water Shrew ranges from the northeastern United States to northern Canada, west to Alaska, and southward into Utah and New Mexico, but is confined to the Appalachian Mountains in the southeastern United States (Ford et al. 2006, Hall 1981, Laerm et al. 2007, Pagels et al. 1998, Reid 2006). It is found along cold mountain streams and bogs.

Our data were consistent with the currently accepted distribution (Fig. 3). Records were found in two areas within the Southern Appalachians: (1) north Georgia and along the North Carolina/Tennessee line and (2) Highland and Bath counties in north-central Virginia. Because no records were found between the two areas, it is plausible that two separate populations of the American Water Shrew exist in the Appalachians. However, because standard capture methods for soricids are not effective for the American Water Shrew (Ford et al. 2006), it is typically not represented in standard soricid surveys. The gap in the distribution may reflect lack of targeted effort for the species, and it may be more abundant than museum collections indicate (Whitaker and Hamilton 1998). However, considerable searching by Pagels et al. (1998) produced few specimens. It is likely that this species is very rare in the Southern Appalachian Mountains and exists as two widely isolated populations.

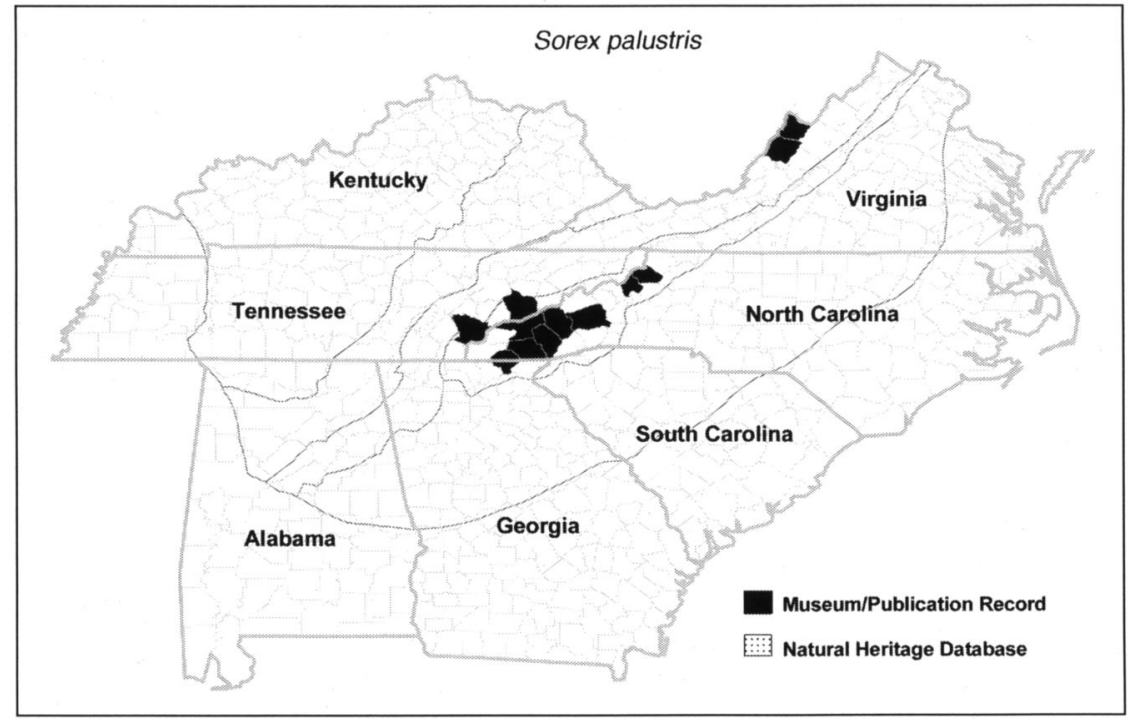

Figure 3. Counties with confirmed museum or publication records for Sorex palustris (American Water Shrew) within the Southern Appalachian Mountains. 


\section{Lepus americanus Erxleben (Snowshoe Hare)}

The Snowshoe Hare is found throughout Canada and parts of the western United States. In the southern United States, it is restricted to only a few high-elevation locations (Hall 1981). It prefers high-elevation wetlands and forest thickets. Little is known about Snowshoe Hares inhabiting the Southern Appalachians (Chapman 2007a).

Only five museum records from two counties (Buncombe County, NC and Highland County, VA) were located (Fig. 4). Residents reported sightings of the species in Cocke County, TN in the 1930s, but specimens have not been collected (Linzey 1995). There is a wide geographical gap between the museum records in Virginia and North Carolina. The record from Buncombe County, NC is from the 1890 s, and this population may no longer be extant.

\section{Sylvilagus obscurus Chapman, Cramer, Deppenaar, and Robinson (Appalachian Cottontail)}

Chapman et al. (1992) reclassified Sylvilagus transitionalis Bangs (New England Cottontail) into two species, $S$. transitionalis and $S$. obscurus. The Appalachian Cottontail is restricted to high-elevation woodlands and mountain balds within the Appalachian Mountains from the Hudson River in New York south to Alabama (Chapman 2007b, Chapman et al. 1992). In many states, the population status is considered undetermined and it is listed as a species of special concern. Overall, the distribution is not well documented (Chapman et al. 1992, Sole 1999).

Museum $(n=61)$ and publication records illustrate that the Appalachian Cottontail is not restricted to the Appalachian region (Fig. 5). Several records are reported from the Interior Low Plateau in Alabama (Chapman 2007b). Although the populations in Alabama appear disjunct from the

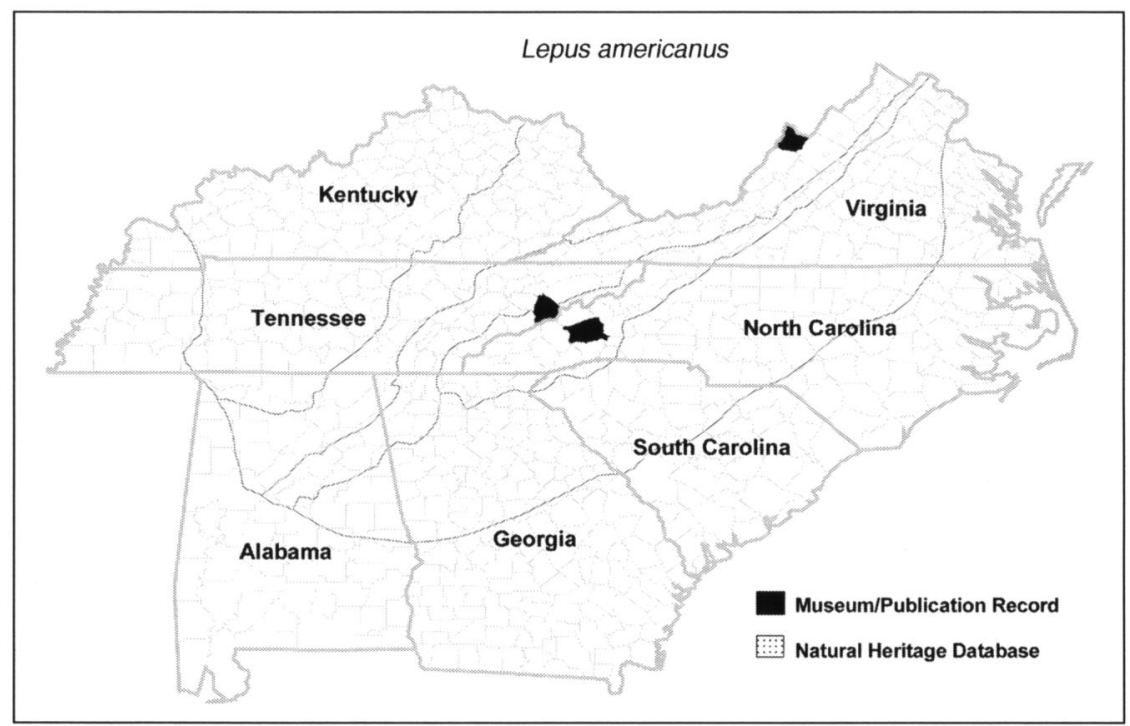

Figure 4. Counties with confirmed museum or publication records for Lepus americanus (Snowshoe Hare) within the Southern Appalachian Mountains. 
primary distribution, the apparent gap in the distribution may reflect a lack of trapping effort.

\section{Microtus chrotorrhinus (Miller) (Rock Vole)}

The Rock Vole ranges from northeastern Canada west to Minnesota and south into the Southern Appalachians (Hall 1981, Pagels and Laerm 2007).

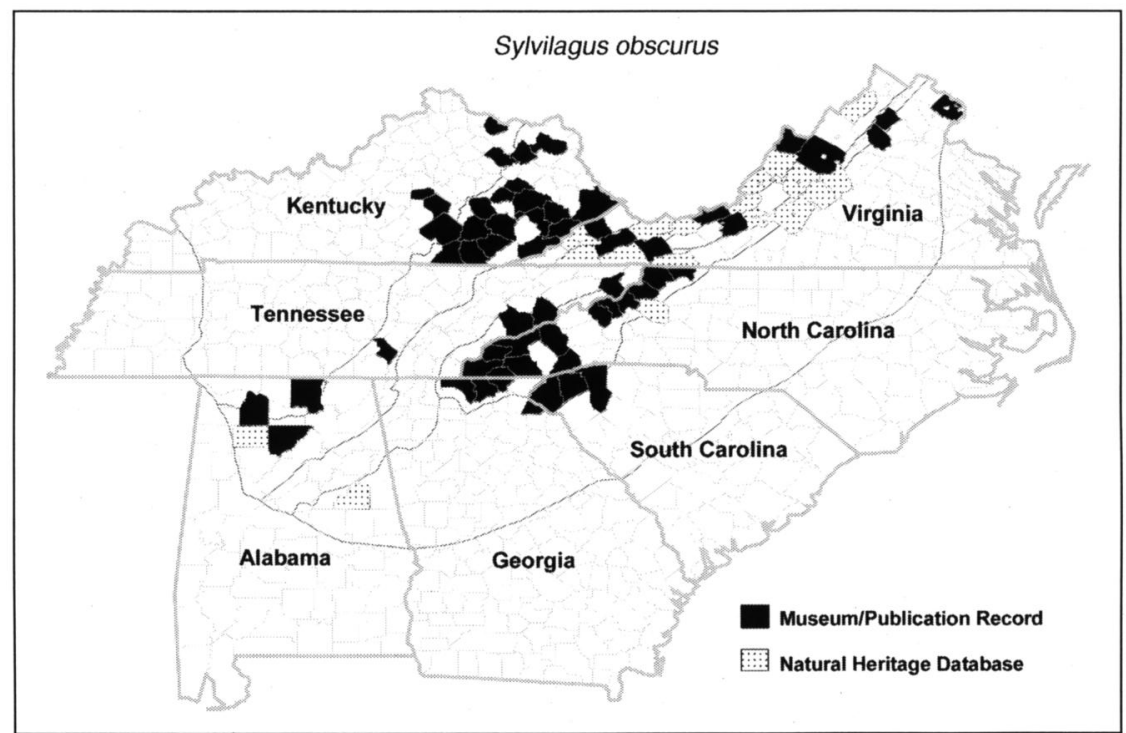

Figure 5. Counties with confirmed museum or publication records for Sylvilagus obscurus (Appalachian Cottontail) within the Southern Appalachian Mountains.

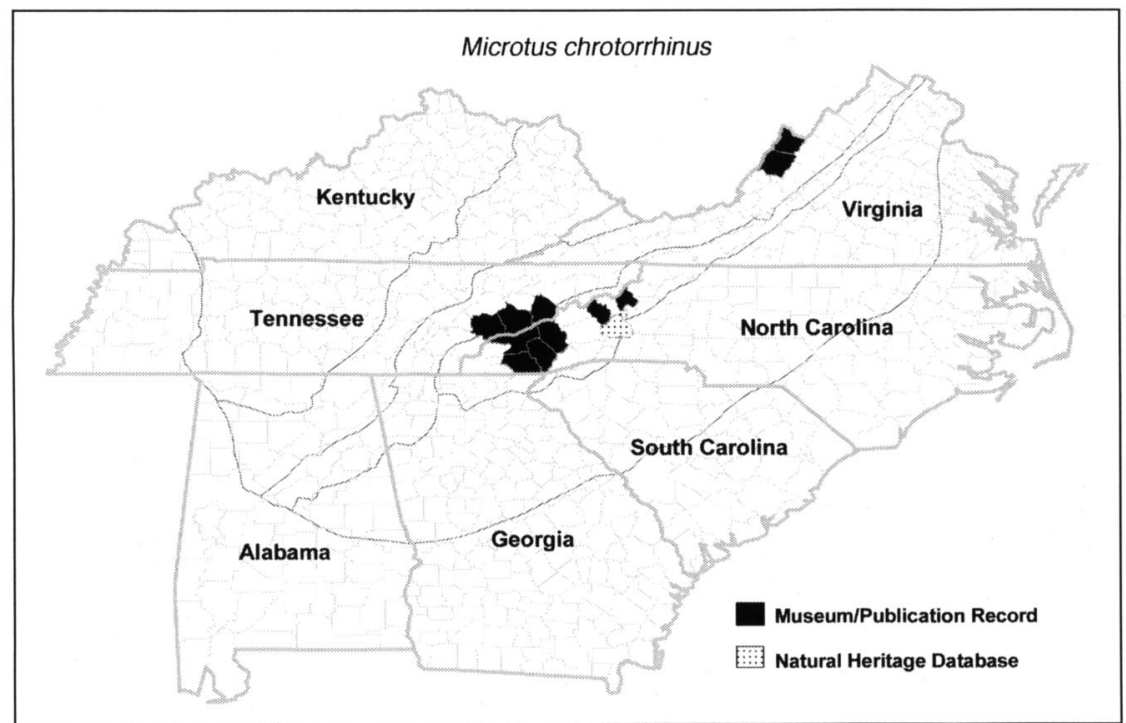

Figure 6. Counties with confirmed museum or publication records for Microtus chrotorrhinus (Rock Vole) within the Southern Appalachian Mountains. 
Rock Voles in the Appalachians may be found in isolated, relict populations (Handley 1992, Linzey 1995). They are found in a variety of habitats throughout their range (Linzey and Linzey 1973), but may prefer mixed mesophytic habitats and moss covered talus or rocks in the Southern Appalachian mountains (Pagels and Laerm 2007).

Our data were consistent with the known ranges in the Southern Appalachians (Fig. 6). Museum and publication records depict a concentration along the Tennessee/North Carolina border that likely reflects the level of effort in the area. Other specimens were found in north-central Virginia (Bath and Highland counties; Pagels 1990). No records were found between the Virginia specimens and the specimens from the Tennessee/North Carolina border. Populations within the southern Appalachians are considered disjunct (Kirkland and Jannett 1982) and our records support the supposition that at least two disjunct populations occur within the Southern Appalachians.

\section{Neotoma magister Baird (Allegheny Woodrat)}

Although previous range maps for the Allegheny Woodrat indicate that this species occurs from Connecticut to north Alabama, it is now thought to be extirpated from New York and Connecticut. Its known range appears to roughly follow the Appalachian Mountain chain, but not exclusively. Allegheny Woodrats have narrow habitat preferences, being closely associated with rock outcrops, cliffs, talus slopes, boulder fields, and cave entrances (Castleberry et al. 2006). Population declines have been documented from the northern part of their range, but they are currently considered secure in the Southern Appalachians (Mengak et al. 2007), although precise ranges and populations are unknown (Castleberry et al. 2006). It is listed as a threatened, endangered, or species of special concern in many states.

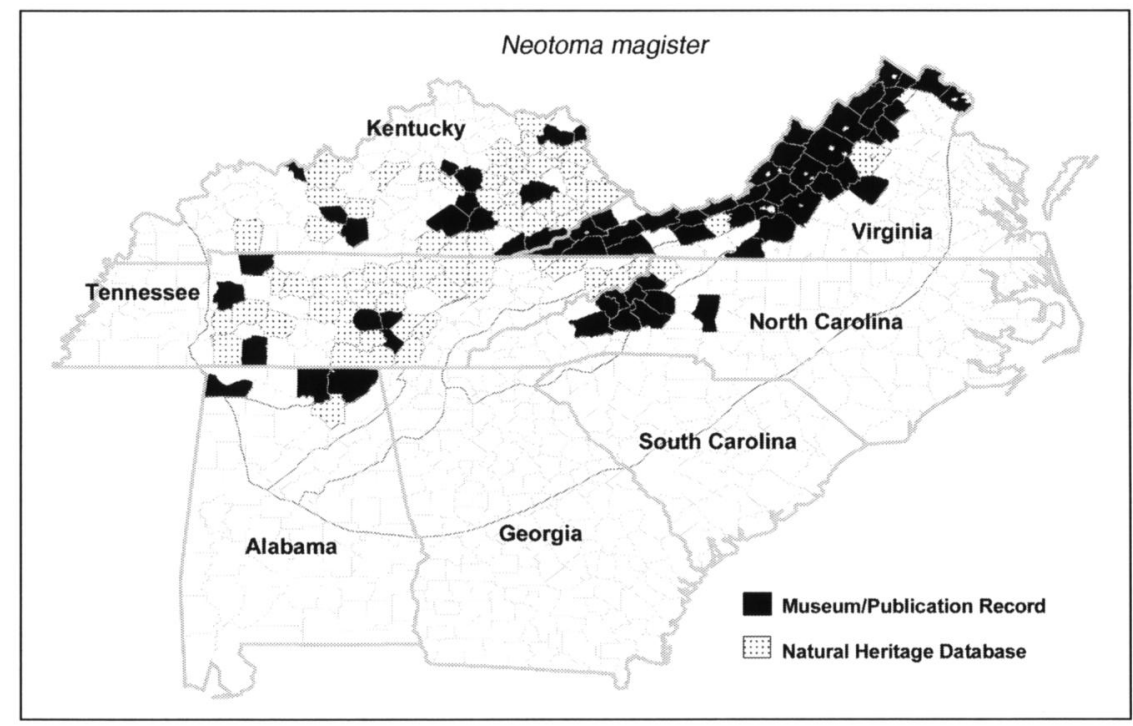

Figure 7. Counties with confirmed museum or publication records for Neotoma magister (Allegheny Woodrat) within the Southern Appalachian Mountains. 
Our data show that the Allegheny Woodrat is found primarily along the Appalachians, but also occurs in the Interior Low Plateau (Fig. 7). The records may indicate, however, that they are found further east in North Carolina and possibly further southwest in Alabama. Neotoma magister was once classified as a subspecies of $N$. floridana ( $N$. f. magister Baird) (Hayes and Richmond 1993). Therefore, specimens labeled as $N$. floridana in some museums might actually be $N$. magister, which could easily provide other county records. Museums should evaluate their records and make the appropriate changes.

\section{Synaptomys cooperi Baird (Southern Bog Lemming)}

The Southern Bog Lemming occurs from southeastern Canada to western Minnesota and southward into southeastern Tennessee (Clark et al. 1993). It inhabits bogs, meadows, and wooded areas (Linzey and Cranford 1984), but habitat preferences and ranges are poorly understood (Ford and Laerm 2007).

Our data show that its distribution may be more widespread in the Southeast than previously thought (Fig. 8). Numerous records from Kentucky and Tennessee show that its range covers a much larger extent than previously known (Robinson 1981) in these two states. Apparently, the Southern Bog Lemming is found throughout Kentucky.

A disjunct population of the Southern Bog Lemming representing the subspecies $S$. c. helaletes Merriam occurs along the Atlantic coast of Virginia and North Carolina (Ford and Laerm 2007). Previously known only from the Dismal Swamp area of Virginia and North Carolina, recent records suggest that the range extends farther into southeastern North Carolina than previously thought (Clark et al. 1993, Webster et al. 1992).

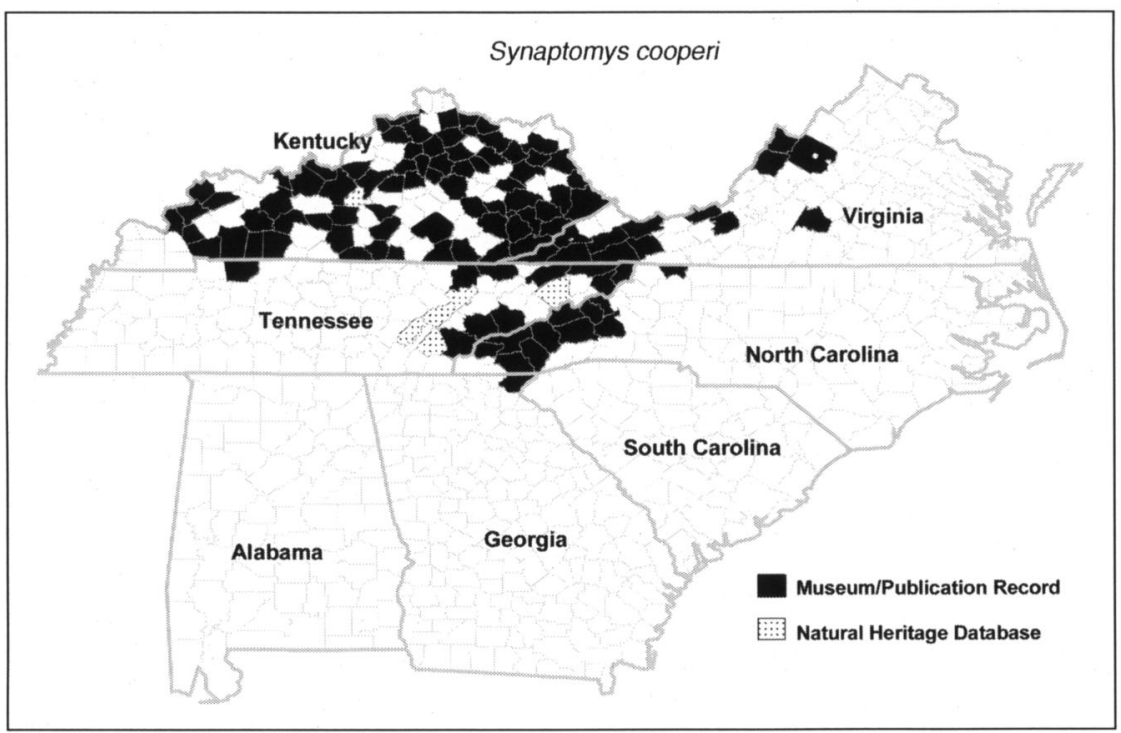

Figure 8. Counties with confirmed museum or publication records for Synaptomys cooperi (Southern Bog Lemming) within the Southern Appalachian Mountains. 


\section{Glaucomys sabrinus (Shaw) (Northern Flying Squirrel)}

The Northern Flying Squirrel is a common species in the northern United States and Canada, with a distribution that extends into southern California, parts of the Southwest, and into the Appalachians (Hall 1981). Its preferred habitat is montane boreal-northern hardwood forests (Ford and Rodrigue 2007). In the Southern Appalachians, it is restricted to high elevations and considered to be rare and a remnant from the Ice Ages (Odom et al. 2001, Pagels et al. 1990). Two subspecies, G. s. fuscus Miller (Virginia Northern Flying Squirrel) in northern Virginia and G. s. coloratus Handley (Carolina Northern Flying Squirrel) in southwestern Virginia and western North Carolina (Hughes 2006), are known to exist within the Southern Appalachians. Both subspecies have been listed as endangered by the US Fish and Wildlife Service since 1985. However, the Virginia Northern Flying Squirrel has been removed from the Endangered Species List (USFWS 2008). Loss of habitat, competition with G. volans (L.) (Southern Flying Squirrel), and parasitic nematodes, may be the main threats to its survival in the Southern Appalachians (Pagels et al. 1990). It remains one of the rarest mammals in this region (Ford and Rodigue 2007).

Collection records indicate that its range is restricted to the Appalachians in the Southeast (Fig. 9). Only three states (Virginia, North Carolina, and Tennessee) in the Southern Appalachian region have records of Northern Flying Squirrels. Future sampling will likely clarify the distribution of Northern Flying Squirrels in this region.

\section{Tamiasciurus hudsonicus (Erxleben) (Red Squirrel)}

The Red Squirrel prefers coniferous forests (primarily spruce), but will inhabit mixed conifer/hardwood forest and mixed hardwood stands (Laerm

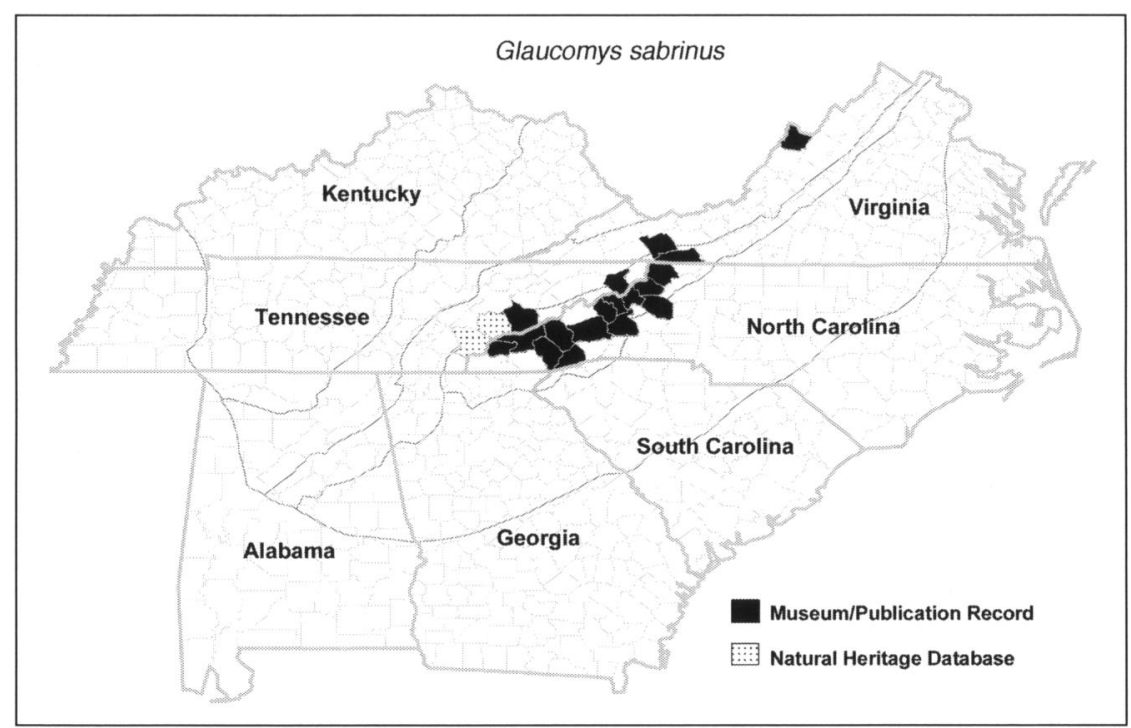

Figure 9. Counties with confirmed museum or publication records for Glaucomys sabrinus (Northern Flying Squirrel) within the Southern Appalachian Mountains. 
and Webster 2007). Red Squirrel densities are dependent on habitat type and possible food competition with gray squirrels (Stevens and Kennedy 1999). Their range includes much of northern North America, Canada, Alaska, portions of the Midwest and the southwestern United States, but also extends south along the Appalachians (Hall 1981, Reid 2006). Within the range, numerous subspecies are defined, but only one is found within the Southern Appalachians (Hall 1981).

The majority of the museum specimens $(n=251)$ and all of the publication data indicate that they are primarily constrained to the Appalachians in the Southeast (Fig. 10). We identified two museum specimens of Red Squirrels from the Piedmont of North Carolina. There was no evidence to suggest that a museum specimen from Warren County (NCSM) had been mislabeled (Lisa Gatens, North Carolina Museum of Natural Sciences, Raleigh, NC, pers. comm.). The other specimen (USNM, Wake County) may have been a captive specimen that escaped. Lee et al. (1982) mentions a specimen from Vance County, NC, but this may have also been a captive release. However, because these counties are in close proximity, these records could indicate a small population of Red Squirrels in the North Carolina Piedmont. Suitable habitat of relict White Pine-Eastern Hemlock (Pinus strobus-Tsuga canadensis) occurs in the North Carolina Piedmont, and additional searching will clarify the distribution in this area. Red Squirrels historically have been known from Piedmont counties in Virginia (Lee et al. 1982), and several specimens reported from Virginia came from counties located in or near the Piedmont.

\section{Napaeozapus insignis (Miller) (Woodland Jumping Mouse)}

The Woodland Jumping Mouse is found throughout the northeastern United States and southeastern Canada, but is limited to the Appalachian

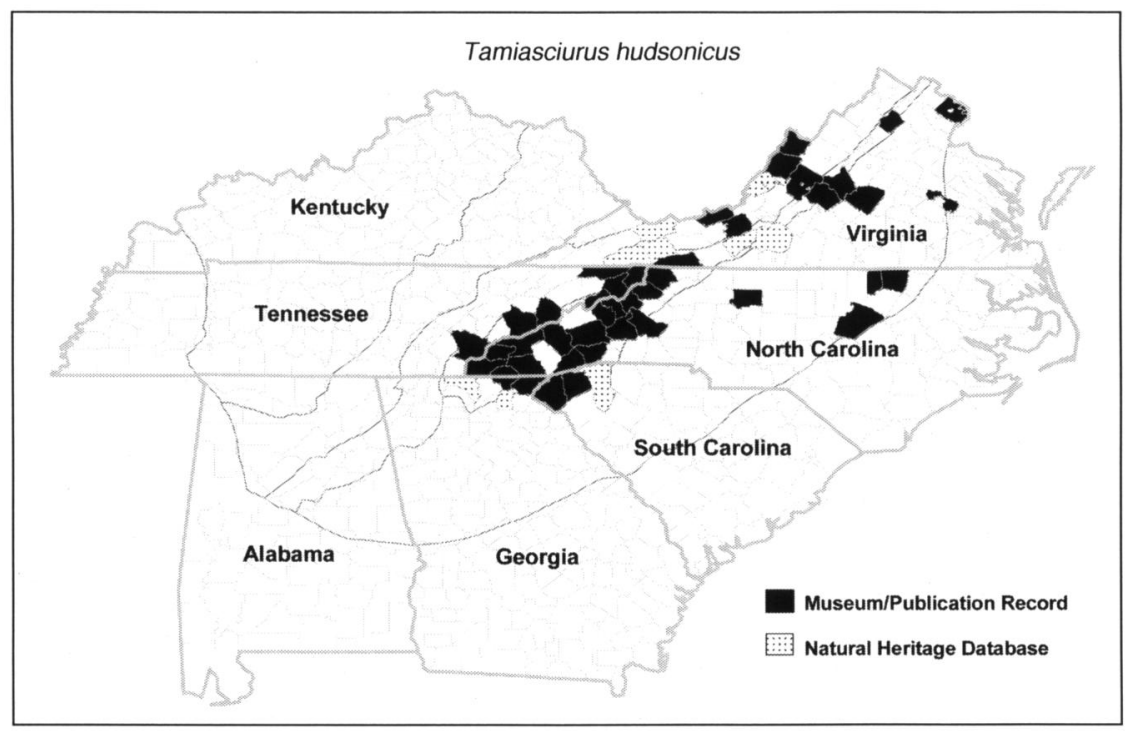

Figure 10. Counties with confirmed museum or publication records for Tamiasciurus hudsonicus (Red Squirrel) within the Southern Appalachian Mountains. 
Mountains in the Southeast (Hall 1981). Its preferred habitat is forested and brushy riparian habitat (Laerm and Pagels 2007a).

Data indicate that the Woodland Jumping Mouse is primarily constrained to the Appalachians in the Southeast (Fig. 11). However, many records from Kentucky illustrate that its range extends further west than previously thought. A record from Cheatham County, TN, shows the range extending much farther west than previously documented (Kennedy and Harvey 1980). A few records in northeast Virginia also suggest an eastward expansion. Despite the depiction of the range extending into Alabama by Burt and Grossenheider (1980), we were unable to identify museum or publication records from the state (Reid 2006). Whitaker and Wrigley (1972) do not show $N$. insignis in Alabama.

\section{Zapus hudsonius (Zimmermann) (Meadow Jumping Mouse)}

The Meadow Jumping Mouse is found from Alabama to eastern Canada and throughout the Midwest, north to southern Alaska (Hall 1981). It prefers grasslands, but can be found in a wide array of habitats (Laerm and Pagels 2007b). One subspecies (Z. h. pallidus) is disjunct and outside the geographical scope of this paper (Laerm and Pagels 2007b).

Museum records $(n=155)$ and publications showed minor differences from the known range (Fig. 12). Hall (1981) recognizes two subspecies: $Z$. $h$. americanus Barton throughout most of the Southeast and $Z$. h. intermedius Krutzsch found in the western half of Tennessee and Kentucky. Several county records were found from southwestern Tennessee, which is outside the range of both subspecies. Few records exist from Tennessee, Alabama, and Georgia. Specimens were collected in Alabama in 1976 (Dupree 1977), but recent trapping efforts in Alabama have not documented additional

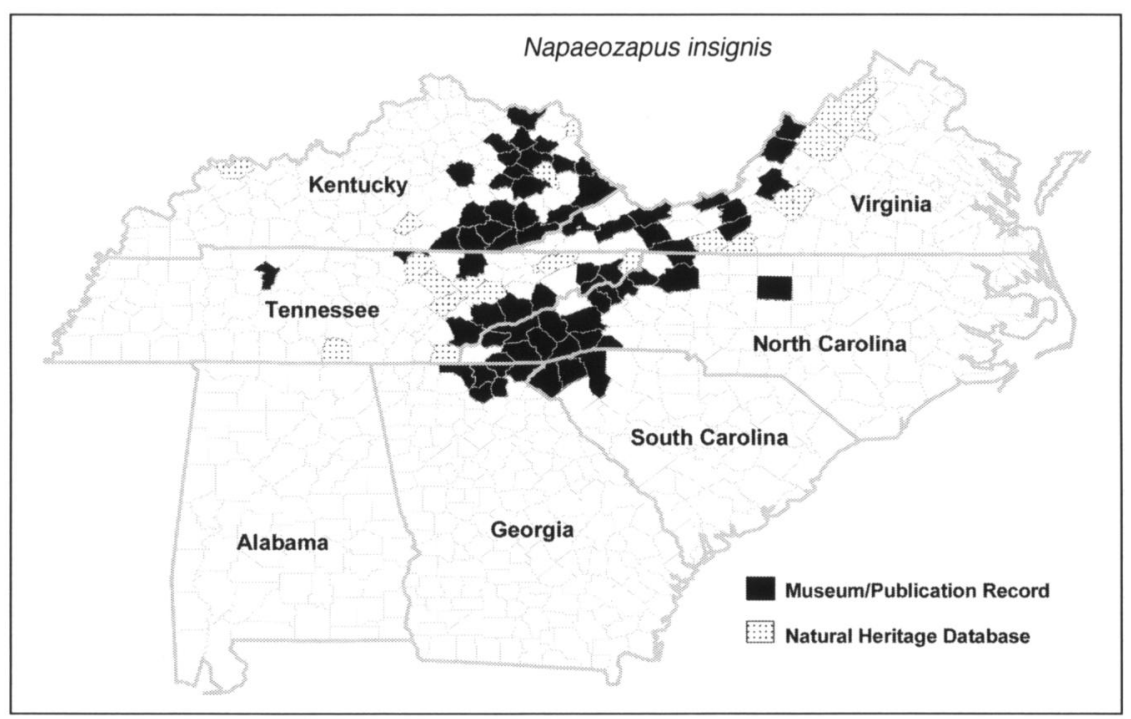

Figure 11. Counties with confirmed museum or publication records for Napaeozapus insignis (Woodland Jumping Mouse) within the Southern Appalachian Mountains. 
specimens (Petra Redinger, Auburn University, Auburn, AL, pers. comm.). We found only a few museum records for eastern Kentucky, middle Tennessee, and northern Georgia (Appendix I). Therefore, the true extent of their range in these states will require further study.

\section{Spilogale putorius (L.) (Eastern Spotted Skunk)}

The range of the Eastern Spotted Skunk includes much of the Southeast and most of the central United States (Hall 1981). The species inhabits numerous habitats, from wooded areas to prairies, but basic habitat preferences are poorly known (Gompper and Hackett 2005). Although Eastern Spotted Skunks are found throughout the Coastal Plain in Alabama and most of Georgia, they are absent from most of the Coastal Plain in South Carolina and all of it in North Carolina and Virginia. However, abundance and specific distribution of Eastern Spotted Skunks in the Southern Appalachians are unclear. Recent trapping efforts in Tennessee suggest that the species is rare (Reed and Kennedy 2000), and few records exist in Virginia.

Our data demonstrate that they are found throughout the Southeast, but are predominant in the Southern Appalachians (Fig. 13). Whether the observed predominance in the region represents the actual abundance of the species or is due to more extensive trapping efforts within this area is unknown. The species is considered rare in Kentucky (Meade 1992), but several records from northern Kentucky indicate that their range may extend further north than reported in Hall (1981). Our records, however, indicate no large range differences from previous sources.

\section{Mustela nivalis L. (Least Weasel)}

The Least Weasel inhabits a wide variety of habitat types including meadows, fields, and open woods. Prey availability largely determines its

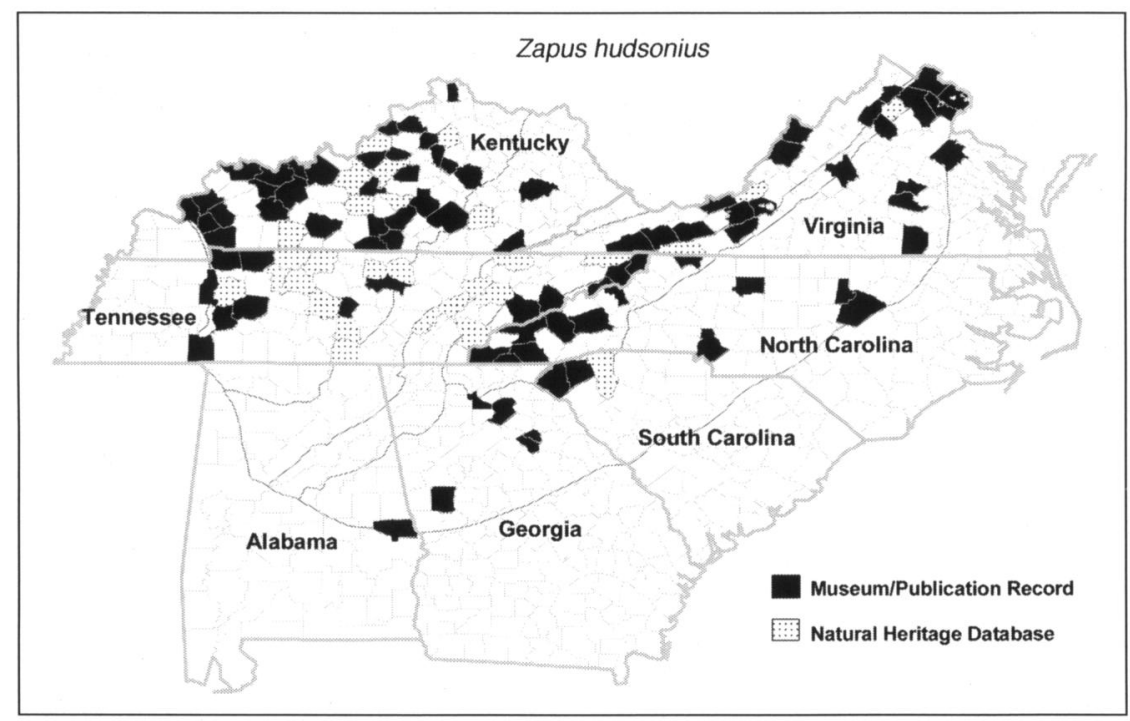

Figure 12. Counties with confirmed museum or publication records for Zapus hudsonius (Meadow Jumping Mouse) within the Southern Appalachian Mountains. 
distribution (Sheffield and King 1994). The known range includes much of northern North America, Alaska, and Canada, but also the Appalachian chain (Hall 1981). In the Southeast, they are considered rare or of special concern in several states (Laerm et al. 2000).

Museum records $(n=17)$ and several recent publications show their range extending much further into the Southeast than previously thought

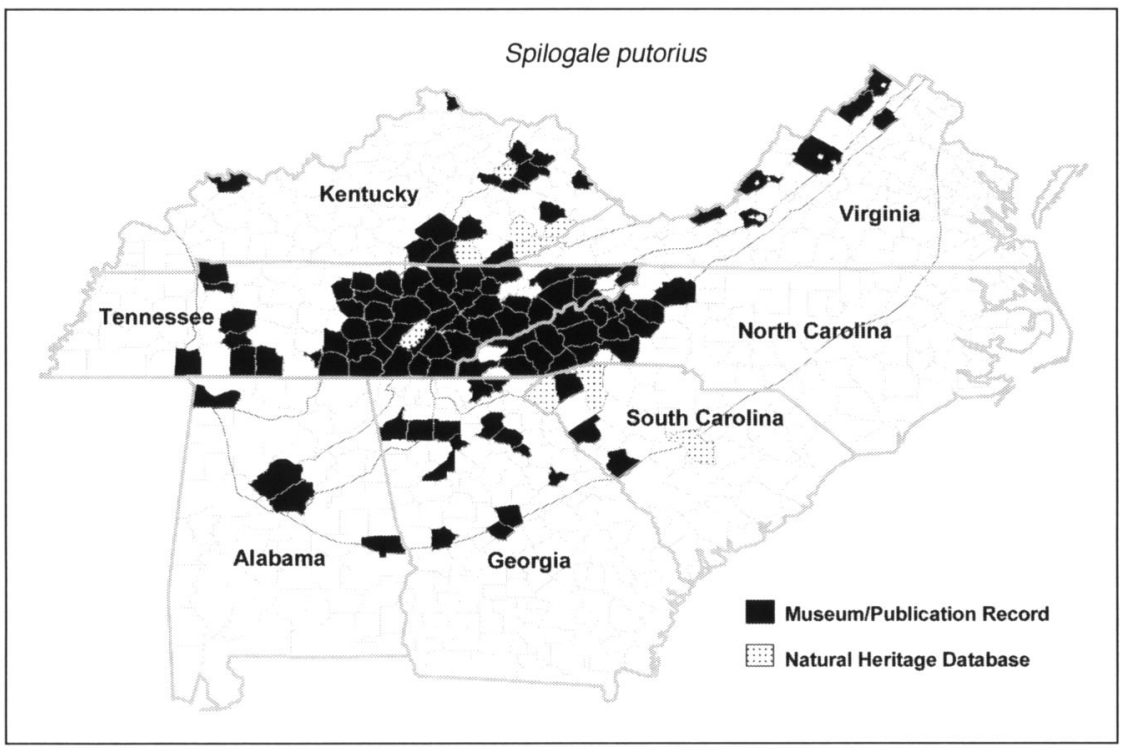

Figure 13. Counties with confirmed museum or publication records for Spilogale putorius (Eastern Spotted Skunk) within the Southern Appalachian Mountains.

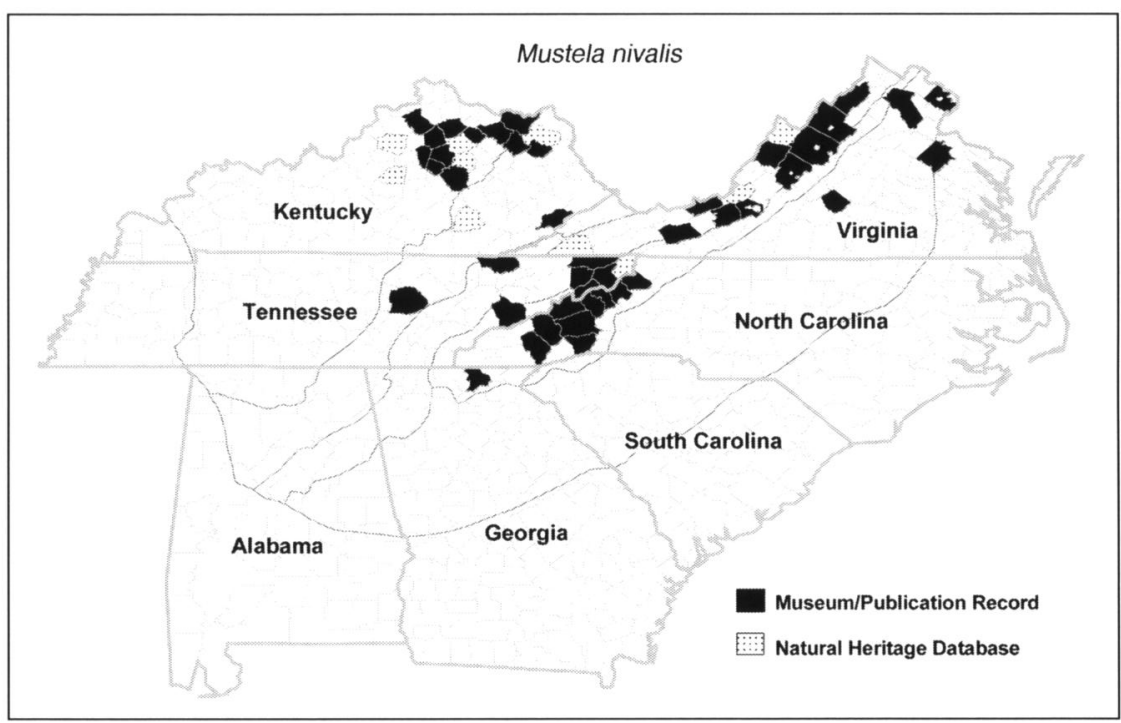

Figure 14. Counties with confirmed museum or publication records for Mustela nivalis (Least Weasel) within the Southern Appalachian Mountains. 
(Fig. 14). Numerous records from western Kentucky and middle Tennessee illustrate that they are not strictly confined to the Appalachians. Bellows et al. (1999a) recorded a Least Weasel from Caroline County, VA, which is the first record from the Coastal Plain.

\section{Conclusion}

We documented noticeable differences between ranges derived from the records we compiled and currently accepted ranges (Hall 1981, Reid 2006) for 7 of the species we examined. For 3 species-Woodland Jumping Mouse, Least Weasel, and Red Squirrel-we documented distributional records in counties $>150 \mathrm{~km}$ from the currently accepted range. For 4 additional species-Rock Shrew, Southern Bog Lemming, Allegheny Woodrat, and Meadow Jumping Mouse-we documented distribution records less distant $(<75 \mathrm{~km})$ from the currently accepted range. Because ours represents the first comprehensive review of distributional records of southeastern mammals since Hall (1981), the range extensions documented likely reflect additional collections and publication records in the past 30 years. Additionally, distribution maps in Hall (1981) were derived from museum records, whereas ours combined museum, publication, Natural Heritage, and personal communication records. We gave each observation equal weight, but further collecting may be necessary to establish a permanent record of some observations. Other students of mammalogy and natural history may revise our range maps or choose a different suite of species to document.

We selected species based on their apparent rarity in the region, with the goal of providing distributional information needed to develop effective management strategies. We acknowledge that other, or additional, species could have been selected. The species we selected are considered globally secure (G4 or G5). However, most rank between S1 and S3 at the state level (Trani et al. 2007), and the Northern Flying Squirrel was only recently removed from the endangered species list (USFWS 2008). Only the Red Squirrel, Woodland Jumping Mouse, and Meadow Jumping Mouse have state rankings of S3 or higher in all of the states we studied (Trani et al. 2007). Southern Bog Lemming, Long-tailed Shrew, American Water Shrew, Snowshoe Hare, Rock Vole, Least Weasel, and Eastern Spotted Skunk have classifications of $\mathrm{S} 1$ in at least one state in our study. Although these rankings may reflect actual rarity, in some cases rankings reflect a lack of knowledge about species distribution and abundance. Our results will be useful in assessing species rankings to more accurately reflect actual status. Additionally, accurate knowledge of distributions will aid in developing management plans, setting habitat acquisition priorities, and directing research for these apparently sensitive species (Fields 2007).

\section{Acknowledgments}

We thank Dan Holliman, Nancy Simmons, Ned Gilmore, Sue McLaren, Stanlee Miller, William Stanley, Jim Dines, Laura Abraczinskas, Terry Derting, Robert 
Martin, Lisa Gatens, Craig Ludwig, Marcia A. Revelez, Elizabeth McGhee, Barbara Clauson, Stephen H. Hinshaw, Timothy J. Gaudin, John Rozdilsky, Nancy Moncrief, and Llyn Sharp for providing museum specimen data. We also thank Alvin R. Diamond, Danny Ray, Chris McGrath, Timothy Gaudin, and John Pagels for reviewing the maps and contributing additional county records. The manuscript was improved with the thoughtful suggestions of two anonymous reviewers and the guest editor.

\section{Literature Cited}

Anderson, B.F. 1988. Occurrence of the Least Weasel (Mustela nivalis) in Cumberland County, Tennessee. Journal of the Tennessee Academy of Science 63:82.

Baker, R.J., L.C. Bradley, R.D. Bradley, J.W. Dragoo, M.D. Engstrom, R.F. Hoffmann, C.A. Jones, F. Reid, D.W. Rice, and C. Jones. 2003. Revised checklist of North American mammals north of Mexico, 2003. Occasional Papers, Museum of Texas Tech University, Lubbock, TX. Number 229, December 2003.

Bellows, A.S., J.F. Pagels, and J.C. Mitchell. 1999a. First record of the Least Weasel, Mustela nivalis (Carnivora: Mustelidae), from the Coastal Plain of Virginia. Northeastern Naturalist 6:38-40.

Bellows, A.S., J.C. Mitchell, and J.F. Pagels. 1999b. Small-mammal assemblages on Fort A.P. Hill, Virginia: Habitat associations and patterns of capture success. Banisteria 14:3-14.

Brooks, M. 1971. The Southern Appalachians. 1-11, In P.C. Holt (Ed.). Distributional History of the Biota of the Southern Appalachians. Part III: Vertebrates. Symposium by Virginia Polytechnic Institute and State University and the Association of Southeastern Biologists. Blacksburg, VA.

Brown, L.N. 1997. A Guide to the Mammals of the Southeastern United States. University of Tennessee Press, Knoxville, TN.

Brown, R.K. 1989. Food habits of Kentucky owls. The Kentucky Warbler 65:38-48.

Bryan, H.D. 1991. The distribution, habitat, and ecology of shrews (Soricidae: Blarina, Sorex, and Cryptotis) in Kentucky. Journal of the Tennessee Academy of Science 66:187-189.

Burt, W.H., and R.P. Grossenheider. 1980. A Field Guide to the Mammals of North America North of Mexico. Houghton Mifflin, New York, NY.

Caldwell, R.S. 1980. First records of Sorex dispar and Microsorex thompsoni in Kentucky with distributional notes on associated species. Transactions of the Kentucky Academy of Science 41:46-47.

Castleberry, S.B., M.T. Mengak, and W.M. Ford. 2006. Neotoma magister. Mammalian Species 789:1-5.

Chapman, B.R. 2007a. Snowshoe Hare. Pp. 226-229, In M. Trani-Griep, W.M. Ford, and B.R. Chapman (Eds.). Land Managers Guide to Mammals of the South. The Nature Conservancy, Durham, NC. 546 pp.

Chapman, B.R. 2007b. Appalachian Cottontail. Pp. 243-246, In M. Trani-Griep, W.M. Ford, and B.R. Chapman (Eds.). Land Managers Guide to Mammals of the South. The Nature Conservancy, Durham, NC. 546 pp.

Chapman, J.A., K.L. Cramer, N.J. Dippenaar, and T.J. Robinson. 1992. Systematics and biogeography of the New England Cottontail, Sylvilagus transitionalis (Bangs, 1895), with the description of a new species from the Appalachian mountains. Proceedings of the Biological Society of Washington 105:841-866.

Clark, M.K., M.S. Mitchell, and K.S. Karriker. 1993. Notes on the geographical and ecological distribution of relict populations of Synaptomys cooperi (Rodentia: Arvicolidae) from eastern North Carolina. Brimleyana 19:155-167. 
Clark, T.M., R.P. Reading, and A.L. Clarke. 1994. Endangered Species Recovery: Finding the Lessons, Improving the Process. Island Press, Washington, DC.

Copeland, J.E., and R.S. Caldwell. 1991. Prey consumed by Barn Owls, Tyto alba, in Claiborne County, Tennessee. Journal of the Tennessee Academy of Science 66:29-30.

Couch, C.R., and J.F. Pagels. 1996. Temporal variation in shrew assemblages: A pitfall removal study. Virginia Journal of Science 47:150.

Cushing, B.S., and F.M. Knight. 1991. Range extension and first reported female Least Weasel in Tennessee. Journal of the Tennessee Academy of Science 66:12.

David, P.G. 1988. Further distribution of Mustela nivalis in Kentucky. Transactions of the Kentucky Academy of Science 49:37.

Dobson, A.P., J.P. Rodriguez, W.M. Roberts, and D.S. Wilcove. 1997. Geographic distribution of endangered species in the United States. Science 275:550-553.

Dupree, W.G. 1977. A study of the distribution and ecology of the Meadow Jumping Mouse (Zapus hudsonius Zimmerman) at the southern extremity of its range. M.Sc. Thesis. Auburn University, Auburn, AL.

Environmental Systems Research Institute (ESRI). 2005. ArcGIS 9.1. ESRI, Redlands, CA.

Fenneman, N.M. 1938. Physiography of the Eastern United States. McGraw-Hill, New York, NY. 714 pp.

Fields, S.E. 2007. Mammals of the north-central Piedmont of South Carolina. Southeastern Naturalist 6:577-596.

Ford, W.M., and J. Laerm. 2007. Southern Bog Lemming. Pp. 381-384, In M. TraniGriep, W.M. Ford, and B.R. Chapman (Eds.). Land Managers Guide to Mammals of the South. The Nature Conservancy, Durham, NC. 546 pp.

Ford, W.M. and J.L. Rodrigue. 2007. Northern Flying Squirrel. Pp. 389-394, In M. Trani-Griep, W.M. Ford, and B.R. Chapman (Eds.). Land Managers Guide to Mammals of the South. The Nature Conservancy, Durham, NC. 546 pp.

Ford, W.M., T.S. McCay. M.A. Menzel, W.D. Webster, C.H. Greenberg, J. F. Pagels, and J. Merritt. 2006. Influence of elevation and forest type on shrew community assemblage and species distribution in the central and southern Appalachians. Pp. 303-315, In J.F. Merritt, S. Churchfield, R. Hutterer, and B.A. Sheftel (Eds.). Advances in the Biology of the Shrews II. Special Publication No. 1 of the International Society of Shrew Biologists, New York, NY. 468 pp.

Golley, F.B. 1962. Mammals of Georgia: A Study of their Distribution and Functional Role in the Ecosystem. University of Georgia Press, Athens, GA.

Gompper, M.E., and H.M. Hackett. 2005. The long-term, range-wide decline of a once common carnivore: The Eastern Spotted Skunk (Spilogale putorius). Animal Conservation 8:195-201.

Hackett, H.M., and J.F. Pagels. 2003. Nest site characteristics of the endangered Northern Flying Squirrel (Glaucomys sabrinus coloratus) in southwest Virginia. American Midland Naturalist 150:321-331.

Hafner, M.S., W.L. Gannon, J. Salazar-Bravo, and S.T. Alvarez-Castaneda. 1997. Mammal collections in the western hemisphere: A survey and directory of existing collections. Special Publication of the American Society of Mammalogists. Allen Press, Lawrence, KS. 97 pp.

Hall, E.R. 1981. The mammals of North America. John Wiley and Sons, New York, NY.

Handley, C.O., Jr. 1991. Mammals. Pp. 539-616, In K. Terwilliger (Ed.). Virginia's Endangered Species, Proceedings of a Symposium. Nongame and Endangered Species Program. Virginia Department of Game and Inland Fisheries. The McDonald and Woodward Publishing Company, Blacksburg, VA. 
Handley, C.O., Jr. 1992. Terrestrial mammals of Virginia: Trends in distribution and diversity. Virginia Journal of Science 44:19-26.

Hayes, J.P., and M.E. Richmond. 1993. Clinal variation and morphology of woodrats (Neotoma) of the eastern United States. Journal of Mammalogy 74:204-216.

Houtcooper, W.C. 1982. Current distribution and status of jumping mice (Zapodidae) in Kentucky. Transactions of the Kentucky Academy of Science 43:97-102.

Hughes, R.S. 2006. Home ranges of the endangered Carolina Northern Flying Squirrel (Glaucomys sabrinus coloratus) in the Unicoi Mountains of North Carolina. Proceedings of the Southeast Association of Fish and Wildlife Agencies 60:19-24.

Kalko, E.K.V., and C.O. Handley, Jr. 1993. Comparative studies of small-mammal populations with transects of snap traps and pitfall arrays in southwest Virginia. Virginia Journal of Science 44:3-18.

Kennedy, M.L., and M.J. Harvey. 1980. Mammals. In D.G. Eagar and R.M Hatcher (Eds.). Tennessee's Rare Wildlife. Vol I. The Vertebrates. Tennessee Wildlife Resources Agency, Nashville, TN

Kirkland, G.L., and F.J. Jannett, Jr. 1982. Microtus chrotorrhinus. Mammalian Species 180:1-5.

Krupa, J.J., and K.E. Haskins. 1996. Invasion of the Meadow Vole (Microtus pennsylvanicus) in southeastern Kentucky and its possible impact on the Southern Bog Lemming (Synaptomys cooperi). American Midland Naturalist 135:14-22.

Laerm, J., and J.F. Pagels. 2007a. Woodland Jumping Mouse. Pp. 426-429, In M. Trani-Griep, W.M. Ford, and B.R. Chapman (Eds.). Land Managers Guide to Mammals of the South. The Nature Conservancy, Durham, NC. 546 pp.

Laerm, J., and J.F. Pagels. 2007b. Meadow Jumping Mouse. Pp. 430-434, In M. Trani-Griep, W.M. Ford, and B.R. Chapman (Eds.). Land Managers Guide to Mammals of the South. The Nature Conservancy, Durham, NC. 546 pp.

Laerm, J., and W.D. Webster. 2007. Red Squirrel. Pp. 422-425, In M. Trani-Griep, W.M. Ford, and B.R. Chapman (Eds.). Land Managers Guide to Mammals of the South. The Nature Conservancy, Durham, NC. 546 pp.

Laerm, J., C.H. Wharton, and W.M. Ford. 1995. First record of the Water Shrew, Sorex palustris Richardson (Insectivora: Soricidae), in Georgia with comments on its distribution and status in the southern Appalachians. Brimleyana 22:47-51.

Laerm, J., C.H. Wharton, and W.M . Ford. 1997. The Rock Shrew, Sorex dispar (Insectivora: Soricidae), in Georgia with comments on its conservation status in the southern Appalachians. Brimleyana 22:47-51.

Laerm, J., W.M. Ford, and B.R. Chapman. 2000. Conservation status of terrestrial mammals of the southeastern United States. Pp. 4-16, In B.R. Chapman and J. Laerm (Eds.). Fourth Colloquium on Conservation of Mammals in the Southeastern United States. Occasional Papers of the North Carolina Museum of Natural Sciences and the North Carolina Biological Survey, Raleigh, NC.

Laerm, J., W.M. Ford, and B.R. Chapman. 2007. American Water Shrew. Pp. 101-112, In M. Trani-Griep, W.M. Ford, and B.R. Chapman (Eds.). Land Managers Guide to Mammals of the South. The Nature Conservancy, Durham, NC. 546 pp.

Lee, D.S., J.B. Funderburg, Jr., and M.K. Clark. 1982. A distributional survey of North Carolina mammals. Occasional Papers of the North Carolina Biological Survey 10:1-70. 
LeGrand, Jr., H.E., S.E. McRae, S.P. Hall, and J.T. Finnegan. 2004. Natural Heritage Program List of the rare animal species of North Carolina. North Carolina Natural Heritage Program, Office of Conservation and Community Affairs. NC Department of Environment and Natural Resources, Raleigh, NC.

Linzey, D.W. 1995. Mammals of Great Smoky Mountains National Park-1995 update. The Journal of the Elisha Mitchell Scientific Society 111:1-81.

Linzey, D.W., and A.V. Linzey. 1973. Notes on food of small mammals from Great Smoky Mountains National Park, Tennessee-North Carolina. Journal of the Elisha Mitchell Scientific Society 89:6-14.

Linzey, A.V., and J.A. Cranford. 1984. Habitat selection in the Southern Bog Lemming, Synaptomys cooperi, and the Meadow Vole, Microtus pennsylvanicus, in Virginia. The Canadian Field-Naturalist 98:463-469.

Machniak, A., and C.E. Elliott. 1997. Comparison of Long-eared and Short-eared Owl winter food habits on a reclaimed strip mine in western Kentucky. The Kentucky Warbler 73:58-65.

Meade, L. 1992. New distributional records for selected species of Kentucky mammals. Transactions of the Kentucky Academy of Science 53:127-132.

Mengak, M.T. 2002. Analysis and summary of eleven years of Allegheny Woodrat trapping data in Southwest Virginia, 1990-2000. Final report. Virginia Department of Game and Inland Fisheries, Richmond, VA. 38 pp.

Mengak, M.T., C.M. Butchkoski, D.J. Feller, and S.A. Johnson. 2007. Lessons form long-term monitoring of woodrat populations. Pp. 109-132 in J.D. Peles and J. Wright (Eds.). The Allegheny Woodrat: Ecology, Conservation, and Management of a Declining Species. Springer-Verlag New York, NY.

Menzel, M.A., B.R. Chapman, W.M. Ford, J.M. Menzel, and J. Laerm. 2000. A review of the distribution and roosting ecology of bats in Georgia. Georgia Journal of Science 58:143-178.

Menzel, J.M., M.A. Menzel, W.M. Ford, J.W. Edwards, S. R. Sheffield, J.C. Kilgo, and M.S. Bunch. 2003. The distribution of the bats of South Carolina. Southeastern Naturalist 2:121-152.

Mitchell, M.S., K.S. Karriker, E.J. Jones, and R.A. Lancia. 1995. Small-mammal communities associated with pine plantation management of pocasins. Journal of Wildlife Management 59:875-881.

O'Conner, B.M. 1985. Mites (Acari) associated with the Long-tailed Shrew, Sorex dispar (Insectivora: Soricidae), in Tennessee. American Midland Naturalist 114:184-187.

Odom, R.H., W.M. Ford, J.W. Edwards, C.W. Stihler, and J.M. Menzel. 2001. Developing a model for the endangered Virginia Northern Flying Squirrel (Glaucomys sabrinus fuscus) in the Allegheny Mountains of West Virginia. Biological Conservation 99:245-252.

Orrock, J.L., E.K. Harper, J.F. Pagels, and W.J. McShea. 1999. Additional records of the Rock Vole, Microtus chrotorrhinus (Miller) (Mammalia: Rodentia: Muridae), in Virginia. Banisteria 14:36-38.

Pagels, J.F. 1987. The Pygmy Shrew, Rock Shrew, and Water Shrew: Virginia's rarest shrews (Mammalia: Soricidae). Virginia Journal of Science 38:364-368.

Pagels, J.F. 1990. First record of the Rock Vole, Microtus chrotorrhinus (Miller) (Rodentia: Cricetidae), in Virginia. Brimleyana 16:1-3.

Pagels, J.F. and J. Laerm. 2007. Rock Vole. Pp. 276-279, In M. Trani-Griep, W.M. Ford, and B.R. Chapman (Eds.). Land Managers Guide to Mammals of the South. The Nature Conservancy, Durham, NC. 546 pp. 
Pagels, J.F., R.P. Eckerlin, J.R. Baker, and M.L. Fies. 1990. New records of the distribution and the intestinal parasites of the endangered Northern Flying Squirrel, Glaucomys sabrinus (Mammalia: Sciuridae), in Virginia. Brimleyana 16:73-78.

Pagels, J.F., L.A. Smock, and S.H. Sklarew. 1998. The Water Shrew, Sorex palustris Richardson (Insectivora: Soricidae), and its habitat in Virginia. Brimleyana 25:120-134.

Prather, K.W. 1984. New distributional record for Mustela nivalis in Kentucky. Transactions of the Kentucky Academy of Science 45:76.

Redington, R.J. 1978. Survey of the Appalachians. Taconic Publishers, South Egremont, MA, USA.

Reed, A.W., and M.L. Kennedy. 2000. Conservation status of the Eastern Spotted Skunk Spilogale putorius in the Appalachian Mountains of Tennessee. American Midland Naturalist 144:133-138.

Reid, F.A. 2006. Mammals of North America. Fourth Edition. Peterson Field Guides. Houghton Mifflin, New York, NY.

Robinson, T.S. 1981. A contribution to the biology of the Southern Bog Lemming in Kentucky. Transactions of the Kentucky Academy of Science 42:90-94.

Roble, S.M., and C.S. Hobson. 2000. Previously overlooked records of the Least Weasel (Mustela nivalis) from Virginia. Banisteria 16:49-50.

Russell, K.R., C.E. Moorman, and D.C. Guynn, Jr. 1999. Appalachian Cottontails, Sylvilagus obscurus (Lagomorpha: Leporidae), from the South Carolina mountains with observations on habitat use. Journal of the Elisha Mitchell Scientific Society 115:140-144.

Savage, T. 1967. The diet of rattlesnakes and copperheads in the Great Smoky Mountains National Park. Copeia 1:226-227.

Sheffield, S.R., and C.M. King. 1994. Mustela nivalis. Mammalian Species. American Society of Mammalogists 454:1-10.

Smith, C.R., J. Giles, M.E. Richmond, J. Nagel, and D.W. Yambert. 1974. The mammals of northeastern Tennessee. Journal of the Tennessee Academy of Science 49:88-94.

Smith, L.L., D.A. Steen, J.M. Stober, M.C. Freeman, S.W. Golladay, L.M. Conner, and J. Cochrane. 2006. The vertebrate fauna of Ichauway, Baker County, GA. Southeastern Naturalist 5:599-620.

Sole, J.D. 1999. Distribution and habitat of Appalachian Cottontails in Kentucky. Proceedings of the Annual Conference Southeastern Association of Fish and Wildlife Agencies 53:444-448.

Stevens, R.T. 1999. Evaluation of three indices for estimating Red Squirrel Tamiasciurus hudsonicus relative abundance. Journal of the Tennessee Academy of Science 74:83-85.

Stevens, R.T., and M.L. Kennedy. 1999. Red Squirrel, Tamiasciurus hudsonicus, population density in the southern Appalachian mountains. Canadian FieldNaturalist 113:664-667.

Trani, M.K., W.M. Ford, and B.R. Chapman. 2007. The Land Manager's Guide to the Mammals of the South. The Nature Conservancy, Southeastern Region, Durham, NC. 546 pp.

US Fish and Wildlife Service (USFWS). 2008. Endangered and threatened wildlife and plants; Final rule removing the Virginia Northern Flying Squirrel (Glaucomys sabrinus fuscus) from the federal list of endangered and threatened wildlife. Federal Register, 26 August 2008, 50226-50247. 
Webster, W.D., P.B. Colwell, and M.A. Shields. 1984. Noteworthy records of mammals from North Carolina. Journal of the Elisha Mitchell Scientific Society 100:112-115.

Webster, W.D., A.P. Smith, and K.W. Markham. 1992. A noteworthy distributional record for the Dismal Swamp Bog Lemming (Synaptomys cooperi helaletes) in North Carolina. Journal of the Elisha Mitchell Scientific Society 108:89-90.

Whitaker, Jr., J.O., and R.E. Wrigley. 1972. Napaeozapus insignis. Mammalian Species. American Society of Mammalogists 14:1-6.

Whitaker, Jr., J.O., G.S. Jones, and D.D. Pascal. 1975. Notes on mammals of the Fires Creek Area, Nantahala Mountains, North Carolina, including their ectoparasites. The Journal of the Elisha Mitchell Scientific Society 91:13-17.

Whitaker, Jr., J.O., and W.J. Hamilton, Jr. 1998. Mammals of the Eastern United States. Cornell University Press, Ithaca, NY. 
Appendix 1. Numbers of specimens (in parenthesis) from states and counties within our study area and the museum or university that provided the specimen data.

\section{Sorex dispar}

GEORGIA: Rabun - UGAMNH (1)

KENTUCKY: Letcher - USNM (2)

NORTH CAROLINA: Haywood - USNM (1), Macon - UGAMNH (3), Swain USNM (3), Yancey- NCSM (4)

TENNESSEE: Carter - AMNH (2), CUVC (4), USNM (5), Sevier - USNM (6)

VIRGINIA: Bath - USNM (2), Giles - USNM (25), UMMZ (2), Grayson - CUVC (1), Russell - USNM (3), Smyth - USNM (1)

\section{Sorex palustris}

GEORGIA: Towns - UGAMNH (2)

NORTH CAROLINA: Clay - NCSM (1), Jackson - UGAMNH (1), Macon - UGAM$\mathrm{NH}(12)$

TENNESSEE: Sevier -USNM (1)

VIRGINIA: Bath - USNM (1)

\section{Lepus americanus}

NORTH CAROLINA: Buncombe - AMNH (1)

VIRGINIA: Highland - USNM (4)

Sylvilagus obscurus

ALABAMA: Cullman - USNM (1), Lawrence - USNM (2), Madison - UGAMNH (1)

GEORGIA: Fannin- UGAMNH (1), Stephens- CUSC (2), Towns- USNM (2), UnionUSNM (3), UGAMNH (3)

NORTH CAROLINA: Mitchell - USNM (5)

SOUTH CAROLINA: Greenville - CUSC (3), Oconee - CUSC (9), USNM (1), Pickens - CUSC (2)

TENNESSEE: Carter - USNM (1), UKNHM (2), Cocke - USNM (1), SequatchieUSNM (1)

VIRGINIA: Arlington - USNM (1), Augusta - USNM (2), Dickenson - USNM (1), Giles - CM (2), USNM (4), Highland - USNM (6), Montgomery - USNM (1), Russell- USNM (4)

Microtus chrotorrhinus

NORTH CAROLINA: Haywood - CUVC (6), UGAMNH (3), UKNHM (1), UMMZ (2), Swain- LACM (1), USNM (8), UAM (1), UIMNH (1), UTC (2), Yancey $\operatorname{NCSM}(1)$

TENNESSEE: Sevier - CUSC (13), LACM (2), USNM (10), UIMNH (4), UKNHM (2)

\section{Neotoma magister}

ALABAMA: Colbert - USNM (3), Jackson - ALMNH (2), USNM (6), MadisonALMNH (11), USNM (2), UKNHM (1)

KENTUCKY: Barren - UIMNH (2), Bell - USNM (2), Boyd - USNM (1), BreathittUSNM (1), Carter - UIMNH (1), UKNHM (1), Edmonson - USNM (15), UIMNH (4), Hancock - USNM (4), Laurel - UKNHM (1), Madison - USNM (1), UIMNH (1), Rockcastle - UIMNH (1) 
NORTH CAROLINA: Avery - UKNHM (4), Buncombe - UGAMNH (3), Watauga$\operatorname{NCSM}(1)$

TENNESSEE: Hickman - USNM (2), Lawrence - USNM (1), Montgomery - USNM (1), Sequatchie - USNM (10), UTC (2), Van Buren - UKNHM (1),Warren UGAMNH(1)

VIRGINIA: Bath - USNM (8), Bedford - CUVC (2), USNM (1), Buckingham - USNM (2), Clarke- USNM (1), Fairfax- USNM (25), Giles- USNM (24), UKNHM (5), UMMZ (7), Loudoun - USNM (2), Roanoke - (1), RockbridgeUSNM (1), Russell - UMMZ (1), Shenandoah- USNM (1), Tazewell - USNM (4), UKNHM (1), Washington- USNM (3)

Synaptomys cooperi

GEORGIA: Rabun - USNM (1)

KENTUCKY: Bath - LACM (1), Bell - USNM (14), UIMNH (1), Breckinridge MSUMC (2), Fayette - CM (1), Franklin - USNM (1), Harlan - USNM (1), Livingston - MSUMC (1), Mason - CM (25) UIMNH (1), McCreary - USNM (7), Scott - USNM (1), Rowan - UIMNH (9)

NORTH CAROLINA: Alleghany - CUVC (1), Buncombe - AMNH (9), FMNH (1), CUVC (1), Haywood - CUVC (10), UGAMNH (5), Jackson - UGAMNH (4), Macon - UGAMNH (8), UKNHM (1), Madison - UMMZ (3), Mitchell - ANSP (6), CM (1), USNM (28), UMMZ (6), UWBM (1), Swain - UIMNH (2), Yancey - CUVC (6), NCSM (3), UMMZ (5)

TENNESSEE: Carter - USNM (5), UKNHM (5), UMMZ (1), Hawkins - USNM (1), Sevier - LACM (2), USNM (1), OMNH (1)

VIRGINIA: Augusta - USNM (1), Bath - USNM (1), Giles - USNM (27), UF (1), UMMZ (1), Highland - USNM (7), Lee - USNM (4), UIMNH (1), Montgomery- CM (1), USNM (2), UMMZ (4), Russell - UMMZ (3), Scott - UMMZ (3), Smyth - USNM (5), UMMZ (5), Suffolk - FMNH (1), Tazewell - USNM (16), Washington - UMMZ (1), Wise - USNM (7)

\section{Glaucomys sabrinus}

NORTH CAROLINA: Yancey - NCSM (2), USNM (2), UMMZ (3)

TENNESSEE: Carter - USNM (6), UKNHM (1)

VIRGINIA - Smyth - USNM (1)

Tamiasciurus hudsonicus

GEORGIA: Rabun- UGAMNH (7)

NORTH CAROLINA: Avery - AMNH (3), USNM (2), UGAMNH (1), UMMZ (2), Buncombe - AMNH (1), NCSM (2), USNM (1), UKNHM (1), Burke - UMMZ (1), Clay - USNM (1), UF (1), UMMZ (6), Haywood - UGAMNH (1), UMMZ (13), Macon - AMNH (1), CUSC (1), MSB (1), USNM (9), UGAMNH (6), UKNHM (2), UMMZ (2), McDowell - UKNHM (1), Mitchell - USNM (23), UIMNH (4), Swain - ANSP (1), USNM (4), MSU (1), UIMNH (1), Wake - USNM (1), Warren - NCSM (1), Watagua - NCSM (1), Yancey - NCSM (5), USNM (4), UMMZ (1)

SOUTH CAROLINA: Oconee - CUSC (1), Pickens - CUSC (2)

TENNESSEE: Carter - ANSP (1), USNM (5), UKNHM (5), Cocke - USNM (10), Sevier - CUSC (3), LACM (2), UIMNH (1), UMMZ (1), Sullivan - USNM (3) 
VIRGINIA: Alexandria - USNM (6), Amherst - CUVC (1), Arlington - USNM (48), Bath - USNM (1), Fairfax - MVZ (11), USNM (7), Giles - USNM (9), VTMNH (5), Grayson - USNM (5), Highland - USNM (6), Monterey - AMNH (1), Montgomery - VTMNH (2), Nelson - USNM (1), Rockbridge - VTMNH (1)

\section{Napaeozapus insignis}

GEORGIA: Fannin - UGAMNH (2), Lumpkin - UGAMNH (2), Rabun - UGAMNH (5), Towns - UGAMNH (14), Union - UGAMNH (48), White - UGAMNH (1)

KENTUCKY: Bell - USNM (2), Harlan - USNM (1), UIMNH (1), Letcher - USNM (8), Whitley - USNM (1), Madison - USNM (2)

NORTH CAROLINA: Alleghany - CUVC (3), Avery - NCSM (2), USNM (4), Buncombe - UGAMNH (10), Haywood - CAS (2), CUVC (9), Henderson - NCSM (1), Jackson - UGAMNH (3), Macon - CUSC (12), NCSM (3), USNM (1), UGAMNH (174), Mitchell - CM (8), USNM (27), UWBM (7), Polk - NCSM (1), Swain - MSB (1), NCSM (1), UIMNH (1), Transylvania - UAM (1), YanceyCUVC (1), MSB (1), NCSM (5), UMMZ (11)

SOUTH CAROLINA: Oconee - CUSC (17), UGAMNH- (9), USNM (1), PickensCUSC (17)

TENNESSEE: Carter - CM (5), USNM (16), UWBM - (2), Cocke - USNM (1), Pickett - CM (1), Sevier - FMNH (1), OMNH (2), UIMNH (3)

VIRGINIA: Bath - USNM (5), Botetourt - VTMNH (1), Floyd - VMNH (2), GilesUSNM (40), UMMZ (4), VTMNH (1), Grayson - USNM (1), Highland - USNM (3), UMMZ (13), VTMNH (1), Montgomery - USNM (1), VTMNH (1), Rappahannock - USNM (1), Russell - USNM (24), Smyth - USNM (1), UMMZ (3), Tazewell - USNM (9), Wise - UIMNH (2)

\section{Zapus hudsonius}

GEORGIA: Clarke - USNM (1)

KENTUCKY: Bullitt - USNM (1), Franklin - USNM (1), Lyon - USNM (1), McLeanUSNM (3), Ohio - USNM (3), Washington - USNM (1)

NORTH CAROLINA: Alleghany - CUVC (1), Buncombe - AMNH (1), CherokeeUMMZ (2), Forsyth - NCSM (1), Mitchell - USNM (2), UWBM (2), Wake - CAS (2), NCSM (9), USNM (3), UMMZ (1)

SOUTH CAROLINA: Oconee- CUSC (6), Pickens - CUSC (17)

TENNESSEE: Carter - UMMZ (1), UWBM (1), Cocke - CAS (1), Perry - UWBM (2)

VIRGINIA: VMNH (1), Amelia - USNM (1), UMMZ (1), Arlington - USNM (4), Bath - USNM (1), Fairfax - USNM (30), Fauquier - USNM (7), Floyd - VMNH (1), Giles - USNM (3), VTMNH (8), Highland - USNM (1), UMMZ (4), Loudoun - USNM (5), Manassas - USNM (1), Montgomery - VTMNH (4), Nelson - USNM (5), PageUSNM (1), Powhatan - USNM (2), Prince William - USNM (5), Roanoke - VMNH (1), Smyth - UMMZ (2), Warren - USNM (1), Washington - UMMZ (1), Wythe $\operatorname{USNM}(2)$

\section{Spilogale putorius}

ALABAMA: Colbert - USNM (1), Jefferson - ALMNH (2), Lee - UMMZ (7), GEORGIA: Bartow - UGAMNH (1), Bibb - UIMNH (1), Cherokee - UGAMNH (1), Clarke- UGAMNH (1), Floyd- USNM (1), Fulton- LACM (3), USNM (1), HallUGAMNH (1), Jackson - UGAMNH (1), Jones - USNM (1), Talbot - MVZ (3), USNM (2), UKNHM (2), Union - USNM (1) 
NORTH CAROLINA: Buncombe - NCSM (1), Cherokee - USNM (1), Haywood NCSM (2), Jackson - UGAMNH (1), Macon - CUSC (1), UGAMNH (1), UMMZ (2), Madison- UMMZ (1), Mitchell- USNM (9), Yancey- NCSM (1)

SOUTH CAROLINA: Abbeville - CUSC (1), Edgefield - USNM (1), Pickens CUSC (2)

TENNESSEE: Campbell - USNM (1), Johnson - USNM (1)

VIRGINIA: Augusta - USNM (1), Giles - USNM (3), Shenandoah - USNM (1)

\section{Mustela nivalis}

GEORGIA: Union - UGAMNH (1)

KENTUCKY: Fayette - CM (1)

NORTH CAROLINA: Buncombe - NCSM (2), Henderson - USNM (1), Yancey NCSM (2)

TENNESSEE: Carter - USNM (1), Sullivan - USNM (1)

VIRGINIA: Fairfax - USNM (1), Fauquier - USNM (1), Giles- USNM (1), Montgomery - USNM (3), VTMNH (1), Rockingham - USNM (1) 